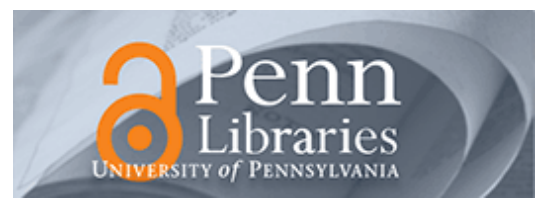

University of Pennsylvania

ScholarlyCommons

Management Papers

Wharton Faculty Research

$10-1-2015$

\title{
Out of the Box? How Managing a subordinate's Multiple Identities Affects the Quality of a Manager-Subordinate Relationship
}

Stephanie J. Creary

University of Pennsylvania

Brianna B. Caza

University of Manitoba

Laura M. Roberts

Antioch University

Follow this and additional works at: https://repository.upenn.edu/mgmt_papers

Part of the Management Sciences and Quantitative Methods Commons

\section{Recommended Citation}

Creary, S. J., Caza, B. B., \& Roberts, L. M. (2015). Out of the Box? How Managing a subordinate's Multiple Identities Affects the Quality of a Manager-Subordinate Relationship. Academy of Management Review, 40 (4), 538-562. http://dx.doi.org/10.5465/amr.2013.0101

At the time of publication, author Stephanie J. Creary was affiliated with Cornell University. Currently, she is a faculty member at the University of Pennsylvania.

This paper is posted at ScholarlyCommons. https://repository.upenn.edu/mgmt_papers/172

For more information, please contact repository@pobox.upenn.edu. 


\title{
Out of the Box? How Managing a subordinate's Multiple Identities Affects the Quality of a Manager-Subordinate Relationship
}

\begin{abstract}
Positive manager-subordinate relationships are invaluable to organizations because they enable positive employee attitudes, citizenship behaviors, task performance, and more effective organizations. Yet extant theory provides a limited perspective on the factors that create these types of relationships. We highlight the important role subordinates also play in affecting the resource pool and propose that a subordinate's multiple identities can provide him or her with access to knowledge and social capital resources that can be utilized for work-based tasks and activities. A manager and a subordinate may prefer similar or different strategies for managing the subordinate's multiple identities, however, which can affect resource utilization and the quality of the manager-subordinate relationship. Our variance model summarizes our predictions about the effect of managers' and subordinates' strategy choices on the quality of managersubordinate relationships. In doing so we integrate three divergent relational theories (leader-member exchange theory, relational-cultural theory, and a positive organizational scholarship perspective on positive relationships at work) and offer new insights on the quality of manager-subordinate relationships.
\end{abstract}

\section{Keywords}

Identity, diversity, resources, relationships, leader-member exchange, relational cultural theory, positive organizational scholarship

\section{Disciplines}

Management Sciences and Quantitative Methods

\section{Comments}

At the time of publication, author Stephanie J. Creary was affiliated with Cornell University. Currently, she is a faculty member at the University of Pennsylvania. 
OUT OF THE BOX?

HOW MANAGING A SUBORDINATE'S MULTIPLE IDENTITIES AFFECTS THE QUALITY OF A MANAGER-SUBORDINATE RELATIONSHIP

February 26, $2015^{1}$

Stephanie J. Creary

Boston College

E-mail : sjcreary@gmail.com

\author{
Brianna Barker Caza \\ University of Manitoba \\ E-mail: brianna.caza@umanitoba.ca
}

Laura Morgan Roberts

Antioch University

E-mail: 1roberts3@antioch.edu

\begin{abstract}
${ }^{1}$ We would like to thank our action editor, Christine Quinn Trank, and our three anonymous reviewers for their feedback and support. We appreciate the feedback we received from audiences at the CGO at Simmons School of Management, the GRO seminar group at Harvard Business School, the Work, Identity and Meaning group at the Boston College Carroll School of Management, the 2012 Positive Relationships at Work Microcommunity research meeting, and the 2013 Academy of Management meeting. Special thanks to Rachel Arnett, Stacy Blake-Beard, Hannah Riley Bowles, Boram Do, Jane Dutton, Robin Ely, Joyce Fletcher, Oscar Holmes IV, Tsedal Neeley, Michael Pratt, Lakshmi Ramarajan, and Andrea Tunarosa for their support. We are grateful to the GDO Division for awarding an earlier version of this paper the Division's Best Student Paper at the 2013 Academy of Management meeting.
\end{abstract}




\title{
OUT OF THE BOX?
}

\section{HOW MANAGING A SUBORDINATE'S MULTIPLE IDENTITIES AFFECTS THE QUALITY OF A MANAGER-SUBORDINATE RELATIONSHIP}

\begin{abstract}
:
Positive manager-subordinate relationships are invaluable to organizations because they enable positive employee attitudes, citizenship behaviors, task performance, and more effective organizations. Yet, extant theory provides a limited perspective on the factors that create these types of relationships. In this paper, we highlight the important role that subordinates also play in affecting the resource pool and propose that a subordinate's multiple identities can provide him or her with access to knowledge and social capital resources that can be utilized for work-based tasks and activities. Yet, a manager and a subordinate may prefer similar or different strategies for managing the subordinate's multiple identities, which can affect resource utilization and the quality of the manager-subordinate relationship. Our variance model summarizes our predictions about the effect of managers' and subordinates' strategy choices on the quality of manager-subordinate relationships. In doing so we integrate three divergent relational theories (i.e., leader-member exchange theory, theory, and a positive organizational scholarship perspective on positive relationships at work) and offer new insights on the quality of manager-subordinate relationships.
\end{abstract}

Keywords: Identity, diversity, resources, relationships, leader-member exchange, relationalcultural theory, positive organizational scholarship 
For decades, scholars and practitioners alike have strived to find ways to cultivate positive manager-subordinate relationships (e.g., Dienesch \& Liden, 1986; Dutton \& Ragins, 2007; Fletcher, 2007; Graen \& Schiemann, 1978; Graen \& Uhl-Bien, 1995; Sparrowe \& Liden, 2005). Positive manager-subordinate relationships engender feelings of mutual obligation, reciprocity, and affective attachment between managers and subordinates (Dulebohn, Bommer, Liden, Brouer, \& Ferris, 2012). A subordinate is more likely to intentionally create, introduce, and apply his or her new ideas to benefit the organization when his or her relationship with his or her manager is positive (Agarwal, Datta, Blake-Beard, \& Bhargava, 2012; West \& Farr, 1989). Subordinates who exchange support, effort, and other work-relevant resources with their managers are less likely to turnover and are more satisfied with their work organizations (Graen, Liden, \& Hoel, 1982). Given the importance of positive manager-subordinate relationships to both individuals and organizations, significant attention has been paid to understanding their antecedents (for a meta-analysis, see Dulebohn et al., 2012).

Notably, leader-member exchange (LMX) theory has emerged as a dominant theoretical lens for understanding positive manager-subordinate relationships. LMX theory describes and explains the different types of exchange relationships that managers form with their subordinates based on the types of resources exchanged (Dansereau, Graen, \& Haga, 1975). Resources refer to those tangible (e.g., pay) and intangible (e.g., knowledge) forms of support that help employees attain centrally-valued ends (Henderson, Liden, Glibkowski, \& Chaudhry, 2009). According to LMX, low-quality manager-subordinate relationships are those based on the economic exchange of resources directly derived from the employment contract such as pay for performance; whereas high quality manager-subordinate relationships 
involve the social exchange of resources that go beyond the formal employment contract such as a manager's mentoring (Scandura \& Schriesheim, 1994) and sponsorship (Sparrowe \& Liden, 2005) in return for a subordinate's organizational citizenship behaviors (Settoon, Bennett, \& Liden, 1996). To date, LMX research grants managers a prominent role in the resource exchange process and determination of LMX quality since their position and power provides them with legitimate access to and control of work-related resources (Dulebohn et al., 2012). As a result, in LMX theory, subordinates are often delegated to taking a reactionary and supportive role in the resource exchange process.

A positive organizational scholarship (POS) perspective on positive relationships at work (Dutton \& Heaphy, 2003; Ragins \& Dutton, 2007) and relational-cultural theory (RCT) (Jordan, Kaplan, Miller, Stiver, \& Surrey, 1991; Miller \& Stiver, 1997) provide a complementary lens on resource utilization in positive workplace relationships, by emphasizing that both managers and subordinates contribute valued resources. Further, RCT and POS perspectives suggest that positive relationships are marked not only by the mutual contribution of valuable resources, but also by their ability to generate new ones. According to RCT, positive relationships are "growth-promoting" in that each person's contribution to an exchange enables both individuals to have "a fuller recognition of their thoughts and feelings, one that may not have been possible a moment before" (Miller \& Stiver, 1997: 27). A POS perspective on relationships at work defines positive workplace relationships as "an enhanced form of resource exchange....[They] efficiently deploy available resources by more efficiently timing and targeting the resources partners exchange.... They entail the production of new resources of a particularly scarce and valued nature via interactions that give exchanges special significance” (Rousseau \& Ling, 2007: 373). 
The current paper enriches our understanding of the quality of manager-subordinate relationships by integrating and extending LMX theory, RCT, and a POS perspective on relationships at work. We integrate and extend these theories in two ways: first, we focus on alignment between managers and subordinates' strategies for managing the resources that subordinates potentially contribute at work. Second, we feature the distinctive resources that subordinates bring to work based upon their multiple identities. Specifically, the purpose of this paper is to answer the question, "How does managing a subordinate's multiple identities affect the quality of a manager-subordinate relationship?" We define multiple identities as two or more meanings that individuals attach to themselves as a function of their multiple social group memberships (i.e., social identities; Oakes, 1987; Ramarajan, 2014; Tajfel \& Turner, 1979; Turner, 1982) and roles (i.e., role identities; Ashforth, 2001; Burke, 1980; Ramarajan, 2014; Stets \& Burke, 2000; Stryker, 1980; Stryker \& Burke, 2000). While the identity of the manager and subordinate's role relationship, that is, the relational identity (Sluss \& Ashforth, 2007), is one of many identities that also can be part of a subordinate's work identity, we focus on the subordinate's multiple identities at the individual level.

To address this question, our theorizing highlights the important role that subordinates play in affecting the resource pool at work (i.e., net resources available; Hobfoll, 2001), which complements the dominant LMX emphasis on the manager's behavior in this regard. In accordance with research on diversity and identities in organizations, we propose that a subordinate's multiple identities (i.e., a subordinate characteristic) can provide a subordinate with access to valuable resources (i.e., social capital and knowledge) that can be utilized for work-based tasks and activities (Ely \& Thomas, 2001; Hoff, 1999; Roberts, Wooten, \& Davidson, forthcoming). We feature the resource dynamics associated with multiple, rather 
than singular identities at work: this expanded focus allows for a greater understanding of the consequences of including and/or excluding various aspects of one's "whole self" at work (Ferdman \& Roberts, 2013; Fitzsimmons, 2013; Ramarajan \& Reid, 2013). By accounting for the subordinate's multiple identities, resources, and behaviors in our theorizing, our approach responds to the call to include more follower-centered perspectives of manager-subordinate relationships (Liden, Sparrowe, \& Wayne, 1997; Lord \& Brown, 2004; Sparrowe \& Liden, 1997; Vondey, 2008; Wilson, Sin, \& Conlon, 2010) including the role that follower selfidentities play in organizations (Lord \& Brown, 2004; Shamir, House, \& Arthur, 1993; Vondey, 2008).

Second, to date, LMX theory, as the dominant perspective on manager-subordinate relationships, offers a relatively narrow conceptualization of the nature of the resource exchange in manager-subordinate relationships. Existing LMX research typically accounts for transactional resource exchanges between managers and subordinates. In this paper, we build a theory of four distinctive forms of resource utilization: resource suppression, resource exploitation, resource exchange, and resource generation. We draw upon organizational diversity, LMX, POS, and RCT theoretical lenses to describe the antecedents and implications of resource utilization for the quality of manager-subordinate relationships. Namely, we draw on the broader diversity and LMX literatures to explain conditions under which subordinatebased identity-related resources are suppressed or exploited, extant LMX theory to explain conditions under which economic and socio-emotional resources are exchanged, and POS and RCT to explain conditions under which new resources are generated through multiple identity management in manager-subordinate relationships. 
Third, we explain how these under-examined resource utilization dynamics influence the quality of manager-subordinate relationships. We propose that when considered separately, LMX theory, RCT, and a POS perspective on positive relationships at work each provide a limited account of the types of relationships that can arise from resource utilization in manager-subordinate relationships. Therefore, in this paper, we integrate and extend these divergent relational theories to theorize around three types of manager-subordinate relationships, which vary in terms of quality-low-quality, social exchange, and generative relationships. The first two types of relationships are discussed within extant LMX research. The third type, "generative relationships" are marked by the relationship's ability to foster mutual growth and produce additional resources, as supported by POS and RCT. Thus, considering all three perspectives on positive relationships at work together reveals new insights on the quality of manager-subordinate relationships. Further, our examination of a fuller range of resource utilization dynamics charts a new research terrain in the study of the distinct, interpersonal mechanisms that produce beneficial versus detrimental managersubordinate relationships.

Our paper is organized as follows. First, we review research on relationships and resources at work. Second, we explain how a subordinate's multiple identities are managed in the workplace. Third, we develop a typology that organizes four different forms of resource utilization according to whether the manager and subordinates' strategies for managing the subordinates' multiple identities are aligned or misaligned. Finally, we offer propositions and a variance model of: a) how strategy alignment and misalignment can affect resource utilization in the manager-subordinate relationship, and b) how resource dynamics affect the quality of the manager-subordinate relationship. Taken together, the typology of resource 
utilization and the variance model of manager-subordinate relationships offer new insights on multiple identity management, resource utilization, and the quality of manager-subordinate relationships in work organizations.

\section{RELATIONSHIPS AND RESOURCES AT WORK}

Three relational theories have gained currency in the organizational studies literature for explaining resource dynamics within workplace relationships: LMX theory (Graen \& Schiemann, 1978; Liden \& Graen, 1980; Liden et al., 1997), a POS perspective on positive relationships at work (Dutton \& Heaphy, 2003; Ragins \& Dutton, 2007; Rousseau \& Ling, 2007), and RCT (Fletcher, 1999, 2007; Jordan et al., 1991; Miller \& Stiver, 1997). We review each of these in brief since each perspective underlies the assumptions we make in our theorizing about resource utilization in manager-subordinate relationships.

\section{LMX Theory}

LMX theory addresses resource exchange dynamics within manager-subordinate relationships explicitly (Graen \& Schiemann, 1978; Liden \& Graen, 1980; Sparrowe \& Liden, 1997). Building on social exchange theory (e.g., Blau, 1964; Emerson, 1976), LMX theory categorizes two types of resources: economic and socio-emotional. Economic resources are those that address financial needs while socio-emotional resources are those that address social and esteem needs (Cropanzano \& Mitchell, 2005). Drawing on Emerson's (1962) power-dependence theory, LMX theory proposes that managers are thought to control resources that subordinates value and cannot easily obtain elsewhere (Farmer \& Aguinis, 2005). Specifically, LMX theory assumes that managers, as higher-status organizational members, control resource flows in organizations and provide their subordinates with resources based on the manager's assessment of a subordinate's competence (Graen \& Scandura, 1987) and expectations of a subordinate's success (Dulebohn et al., 2012). 
Managers influence the flow of both economic and socio-emotional resources in managersubordinate relationships through such things as contingent reward behavior (i.e., providing feedback, rewards, and recognition for accomplishments) and transformational leadership (e.g., inspiring and motivating subordinates) (Dulebohn et al., 2012). In "high LMX" relationships, managers exchange socio-emotional resources such as advice, social support, career opportunities, and trust with certain subordinates who, in turn, reciprocate with high levels of contribution that enhance a manager's effectiveness (Sparrowe \& Liden, 2005). In contrast, in "low LMX" relationships, managers exchange only formally agreed on economic and contractual assets with subordinates such as pay for performance (Blau, 1964). Sparrowe and Liden (1997: 526) explain, “Leaders, by virtue of their 'linking pin' positions, enjoy the power to decide how to distribute meaningful resources and key opportunities among their subordinates.” By controlling the flow of resources, managers largely determine the quality of LMX relationships (Dulebohn et al., 2012). Yet, scholars have argued that subordinates do influence relationship quality as well since LMX is also dependent on factors such as subordinates' achievement and dependability (Dulebohn et al., 2012).

\section{POS Perspective on Positive Relationships at Work}

Scholars taking a POS perspective on positive relationships at work also address resources in the context of manager-subordinate relationships and suggest that workplace relationships (including but not limited to manager-subordinate relationships) can be a source of resource gain and loss at work (e.g., Dutton \& Ragins, 2007; Rousseau \& Ling, 2007). These scholars frequently draw on conservation of resources (COR) theory to define a resource as any object, personal characteristic, condition, or energy that is valued by an individual or used to attain objects, personal characteristics, conditions, or energies (Hobfoll, 
1989; Hobfoll, 2002). In the context of manager-subordinate relationships, managers can provide subordinates with resources such as emotional and instrumental support to mitigate work- and non-work related conflict and demands (Kossek, Pichler, Bodner, \& Hammer, 2011). At the same time, managers can create social stressors and strains that deplete resources in their relationships with subordinates, including not valuing subordinates' contributions (Ng \& Feldman, 2012) or by creating conditions that contribute to subordinate burnout (Wilk \& Moynihan, 2005).

POS researchers have also proposed conditions under which experiences of positivity in workplace relationships can increase the relationship's capacity to generate resources in the present and the future (Baker \& Dutton, 2007; Dutton \& Heaphy, 2003). Drawing on the broaden-and-build theory's notion of "upward spirals" (Fredrickson, 2003) and insights from RCT on growth-in-connection (Jordan et al., 1991; Miller \& Stiver, 1997), scholars have proposed that high-quality connections (HQCs) (short-term interactions marked by vitality, mutuality, and positive regard; Dutton \& Heaphy, 2003) and generalized reciprocity (Baker \& Dutton, 2007) are factors that contribute to "upward spirals" of human functioning in workplace relationships.

\section{Relational-Cultural Theory}

RCT is a feminist perspective on human growth and development (Jordan et al., 1991; Miller, 1976; Miller \& Stiver, 1997). RCT offers a counter perspective to psychological theories of development that separate self-experience and development from the relationships in which the self is embedded (e.g., Erikson, 1993; Mahler, 1972). The hallmarks of RCT are "self-in-relation," "growth-in-connection," and "mutuality." Viewing the self-in-relation gives primacy to the relational context in developmental processes rather than to one's 
autonomy or independence (Miller, 1976). Growth-in-connection is achieved through mutual empathy (i.e., feeling and thinking something similar to what another person thinks and feels) and mutual empowerment (i.e., each person in the relationship is empowered), which are evident in five outcomes: zest, empowered action, increased sense of worth, new knowledge, and desire for more connection (Miller \& Stiver, 1997). Zest reflects a feeling of increased vitality and energy from the sense of connection. Empowered action refers to motivation to act in the moment of the immediate exchange. Increased sense of worth arises from another person's recognition and acknowledgement of one's own experience. New knowledge is cocreated in an interaction when both members fully contribute their thoughts and experiences while being influenced by the thoughts and experiences of another person. Finally, a desire for more connection arises from increased zest, empowerment, knowledge, and worth in connection.

Though it has not yet been used to directly address resource production, the RCT literature does suggest the generative capabilities of positive relationships. Some scholars propose that a manager-subordinate relationship is positive when it produces growth-inconnection/mutual empowerment (Fletcher, 2007) including new knowledge resources (Fletcher, 1999). Fletcher (1999: 63) proposed, “mutually empowering activities enabled others to produce, achieve, and accomplish work-related goals and activities" including increased knowledge. Dutton and Heaphy (2003: 273) proposed that high-quality connections at work "enliven by providing growth-fostering connections," though the authors were not focused on explaining the resource-producing characteristics of manager-subordinate relationships in particular.

\section{MULTIPLE IDENTITIES AS AN ENERGY RESOURCE AT WORK}


An important element to our theorizing is that there may be valuable resources associated with a subordinate's multiple identities that can be utilized (or not) in managersubordinate relationships. LMX and RCT are relevant in informing our typology and variance model in the next section. Yet, COR theory adds an important aspect to the discussion of how identities can be used as resources, namely, in terms of how individuals access additional resources at work. Here, we review organizational research suggesting that an individual's identity-based knowledge and social capital can be used more instrumentally at work to gain access to or produce other resources.

Drawing on COR theory, organizational scholars have proposed that an individual's multiple identities can be used as an "energy resource" to attain resources at work that promote individual success and well-being (e.g., Caza \& Wilson, 2009; Dutton et al, 2010). Caza and Wilson (2009) found that identifying with multiple social groups enabled certified nurse-midwives (CNMs) to obtain social support from both nurses and midwives. In particular, CNMs held diverse social networks as a result of their multiple identities and, thus, were able to use the social capital from their multiple memberships to seek social support following challenging situations at work. Similarly, Dutton and colleagues (2010) proposed that identities can help individuals to access additional resources at work. Namely, identities can enable individuals to increase the number, diversity, and quality of relationships they have at work, which can help them acquire other resources that will strengthen them in stressful or challenging situations (Linville, 1987). As such, an individual's identities can function as resources that mitigate threats/demands and/or enable an individual to accumulate other resources at work. 
Scholars have also linked an individual's identities and associated resources to the improvement of work and work processes in organizations. Research on diversity in organizations in particular suggests that demographic diversity might increase the pool of resources available to solve work-related problems (Cox \& Blake, 1991; Ely \& Thomas, 2001). In this respect, the contributions that individuals from underrepresented groups make or groups of diverse individuals offer can help organizations gain additional resources. Associated research supports that the knowledge and social capital that individuals have developed as members of different social identity groups are potentially valuable resources at work (Ely \& Thomas, 2001; Fitzsimmons, 2013; Roberts et al., forthcoming). Fitzsimmons (2013) proposed that the knowledge or "cultural schema" that multicultural employees have developed through their memberships in multiple cultural groups can help organizations solve complex global problems. Further, the integration-and-learning perspective on diversity (Ely \& Thomas, 2001; Thomas \& Ely, 1996) proposes that the insights, skills, and experiences individuals have developed as members of different identity groups can be used not only as a resource for gaining entrée into previously inaccessible markets (i.e., to increase social capital), but also as a resource for reconceptualizing and reconfiguring work. In addition, research on dual work identities (Hoff, 1999; Pratt \& Rafaeli, 1997) claims that an individual's identities (and the knowledge and social capital that are available as a function of them) can be used as instrumental support for work tasks and processes. Hoff (1999) found that physician-managers who identified both as physicians and managers used the knowledge and social capital gained from identifying with both groups to persuade their physician peers that change within their organization was necessary and to implement policies directed at that organizational change. 
Hence, hereafter and in accordance with research that has previously linked identities to resources at work, we emphasize a subordinate's knowledge and social capital as the key subordinate-based resources germane to our theorizing.

\section{THE EFFECT OF MANAGING A SUBORDINATE'S MULTIPLE IDENTITIES ON RESOURCE UTILIZATION AND THE QUALITY OF A MANAGER- SUBORDINATE RELATIONSHIP}

In this section, we develop several propositions articulating how managing a subordinate's multiple identities affects resource utilization in work-based tasks and activities and the quality of a manager-subordinate relationship as a consequence. Although we recognize that identities are also managed within groups (cf., DeRue \& Ashford, 2010; Ely \& Thomas, 2001; Polzer, Milton, \& Swann, 2002), we build on and link existing work interested in the relational nature of identity management (e.g., DeRue \& Ashford, 2010; Swann \& Bosson, 2008; Swann, Johnson, \& Bosson, 2009). First, we briefly discuss the different types of strategies (inclusionary or exclusionary) that a manager and a subordinate use for managing the subordinate's multiple identities and the factors that influence each person's preferences. Then, we organize the different strategies along the inclusionary/exclusionary dimension for both the manager and the subordinate, indicating whether strategy use is aligned or misaligned. "Alignment" addresses instances in which a subordinate and a manager both use inclusionary strategies or both use exclusionary strategies. "Misalignment" addresses instances in which a subordinate and a manager use different strategies to manage the subordinate's multiple identities. While the terms "inclusionary" "exclusionary," "alignment," and "misalignment" have been used elsewhere in identity management and diversity literatures (e.g., Ferdman \& Roberts, 2013; Prasad, Pringle, \& Konrad, 2006; Roberts, 2013), we view our theorizing as distinguishable from and complementary to that 
theorizing. Namely, our central focus is on the quality of a manager-subordinate relationship as the primary outcome (cf., Kreiner, Hollensbe, \& Sheep, 2006; Ramarajan \& Reid, 2013). Further, our theorizing applies to the management of multiple identities both in a single domain (i.e., two or more work identities) and spanning different domains (i.e., work and nonwork identities) (cf., Ramarajan \& Reid, 2013; Thomas, 1993).

Consequently, our theorizing yields a $2 \times 2$ matrix comprising four different forms of resource utilization: resource suppression, resource exploitation, resource exchange, and resource production (see Figure 1). Subsequently, we propose a variance model predicting these relationships and how different forms of resource utilization lead to three different types of manager-subordinate relationships (i.e., low-quality, social exchange, generative) (see Figure 2). Since our goal is to explain how managing a subordinate's multiple identities predicts the quality of the manager-subordinate relationship through its affect on resource utilization, a variance model is best suited to our theorizing (Mohr, 1982).

Insert Figure 1 About Here

Insert Figure 2 About Here

Managing a Subordinate's Multiple Identities at Work: Inclusionary and Exclusionary Strategies

Extant relational theories suggest that both manager and subordinate behavior influence relational quality (e.g., Dulebohn et al., 2012; Dutton \& Ragins, 2007; Miller \& 
Stiver, 1997). In this section, we characterize manager and subordinate behavior in terms of the inclusionary and exclusionary strategies each person may use for managing the subordinate's multiple identities. Inclusionary strategies aim to increase the relevance of one or more of the subordinate's identities in work-based tasks and activities. In contrast, exclusionary strategies aim to reduce the salience of one or more of the subordinate's identities or reinforce their irrelevance to work-based tasks and activities. While these strategies may be implicitly activated (e.g., exclusion due to automatically simplifying complex information; Cantor \& Mischel, 1979) or the result of more strategic, deliberate processing (e.g., exclusion with the intent of preventing discriminatory treatment; Ellison, Russinova, MacDonald-Wilson, \& Lyass, 2003), our theorizing is based on preference and choice in strategy selection rather than automaticity. By establishing this important boundary condition, our theorizing is better able to account for how these particular individual-level motivations affect relational outcomes.

Preferences for inclusionary and exclusionary strategies. Inclusionary strategies can include the use of "identity expansion" tactics that communicate explicitly that one is "both A and B" (Roberts \& Creary, 2011) or more indirect signaling tactics (Cialdini, 1989; Roberts \& Roberts, 2007) to communicate that an individual belongs to multiple groups and possesses multiple roles that are significant and related to one another. For example, a physician-manager may discuss with his or her supervisor the ways in which his or her identity as both a physician and a manager can help the organization in its implementation of new patient care policies (Hoff, 1999).

A manager and a subordinate may prefer to use inclusionary strategies for managing the subordinate's multiple identities for different reasons. For example, a manager or a 
subordinate may be conditioned to "value diversity" believing that enacting multiple and different identities at work can be beneficial to their team's work outcomes (Cox \& Blake, 1991; Ely \& Thomas, 2001). Further, a subordinate may prefer to include certain identities because of an ingrained sense of commitment that he or she has to his or her multiple identities (cf., Stryker, 1980; Stryker \& Burke, 2000) and his or her need to feel authentic at work through expressing multiple identities (Roberts, Cha, Hewlin, \& Settles, 2009).

Exclusionary strategies make multiple identities less salient, by grouping them under a new unifying category label (Ladge, Clair, \& Greenberg, 2012); "superordinate" identity (Pratt, Fiol, O'Connor, \& Panico, 2012) or a common identity (e.g. Chatman, Polzer, Barsade, \& Neale, 1998; Gaertner \& Dovidio, 2000). Exclusionary strategies can also involve devaluing one identity for the sake of another (Fadil, 1995; Reybold \& Alamia, 2008; Rosenthal, 1995, 1996; Vroom, 2007); or asserting that one or more identities are not legitimate, relevant, or significant for a task or context (Hoff, 1999; Perlow, 1995; Starrels, 1992; Thomas \& Ganster, 1995).

In some cases, a manager may believe that it is in a subordinate's best interests to exclude certain identities at work. For instance, a manager may believe that excluding certain identities (e.g., community leader or school volunteer) may preserve the subordinate's image as "the ideal worker" who is more committed to his or her work responsibilities than his or her nonwork responsibilities (Acker, 1990). Further, a manager may prefer to exclude additional subordinate identities to reduce intergroup bias and promote fairness among individuals who may believe that other team members will receive preferential treatment for holding certain identities (Crisp, Turner, \& Hewstone, 2010; Thomas \& Ely, 1996) or to comply with a human resource policy that prevents a manager from treating his or her 
subordinates differently based on a social identity. Similarly, a subordinate may prefer to exclude certain identities to protect him/herself from heightened scrutiny (Kanter, 1977) or “hypervisibility” (Blake-Beard \& Roberts, 2004), the backlash effect (Rudman, 1998), stigmatization (Ragins, Singh, \& Cornwell, 2007), or discriminatory treatment (Ellison et al., 2003). Or, a subordinate may be conditioned from prior socialization and past work identities to keep different identities separate while at work (Ramarajan \& Reid, 2013).

In accordance with past research on identity management (Pratt, 2000; Swann \& Bosson, 2008; Swann et al., 2009), we also suggest that a manager's preferences for managing his or her own multiple identities may affect the manager's preference for managing a subordinate's multiple identities. Hence, a manager may expect a subordinate's identity enactment to parallel his or her own (Swann et al., 2009). Further, we acknowledge that managers are responsible for socializing their subordinates so that subordinates' identity enactments are consistent with organizational norms and expectations (Pratt, 2000). Thus, we recognize that a manager's strategy for managing a subordinate's multiple identities may also be borne out of a need to comply with organizational policies.

\section{Strategy Misalignment and Alignment and Resource Utilization}

In this section, we develop several propositions articulating how strategy misalignment or alignment affects the utilization of resources in work-based tasks and activities, yielding four different forms of resource utilization: resource suppression, resource exploitation, resource exchange, and resource production. We suggest that our propositions would apply regardless of the nonwork/work or work/work identity combinations being managed. 
Strategy misalignment and resource suppression. There are two forms of strategy misalignment between a manager and a subordinate. One form of strategy misalignment occurs when a manager uses an exclusionary strategy and a subordinate uses an inclusionary strategy for managing the subordinate's multiple identities. We label resource utilization that arises from this form of misalignment "resource suppression."

As indicated previously, some managers use exclusionary strategies believing that enacting certain identities at work may threaten team process and cohesion. As an example, Harrison and colleagues (1998) found that information exchange is more meaningful in diverse teams when "surface-level" diversity (e.g., racial differences) becomes less important. As a result, some managers may adopt a "post-race, color-blind perspective" that emphasizes parity in order to distance themselves and team members from any discourse related to stereotypes, racism, discrimination, or inequality in the opportunity structure (Gallagher, 2003: 24). In light of this color-blind perspective, some managers may err towards viewing all subordinates in terms of their role-based skills and competencies only and not their nonwork identities. For instance, when a manager is matching consultants to a client's marketing project, she may only consider her subordinates' work qualifications (Jovanovic, 1979; Miller, 1984; Vandenberg \& Scarpello, 1990). Misalignment would occur if the subordinate, instead, views a color-blind perspective as a form of identity suppression that disadvantages him or her and the organization. The subordinate may prefer to use an inclusionary strategy because he believes that his racial/ethnic identity provides access to new and valuable knowledge and skills that can benefit work outcomes. He may request to be assigned to a particular marketing project team wherein individuals from his racial/ethnic background are underrepresented because he believes that his insight would be valuable for 
understanding the needs and motivations of customers who share his racial/ethnic background (i.e., access-and-legitimacy perspective; Ely \& Thomas, 2001). Likewise, the subordinate may bring identity-related social capital, in that clients belonging to his racial/ethnic group may be more likely to trust him by virtue of their shared membership. In this respect, the subordinate believes that his race/ethnicity-based knowledge and social capital could help the team devise and implement a new marketing strategy that will appeal to the client's diverse customer base. This value-in-diversity narrative is examined within the broader diversity literature (i.e., the value-in-diversity hypothesis). Cox and Blake (1991: 49) revealed:

Avon President Jim Preston commented that members of a given cultural group are uniquely qualified to understand certain aspects of the world view of persons from that group...In some cases, people from a minority culture are more likely to give patronage to a representative of their own group. For at least some products and services, a multicultural salesforce may facilitate sales to members of minority culture groups.

Thus, a subordinate with whom the value-in-diversity narrative resonates may wish to emphasize the ways in which his or her racial/ethnic identity could be helpful to the project, using inclusionary strategies to manage his or her multiple identities at work.

This type of strategy misalignment can also ensue when managing a subordinate's work/work identity combination. For example, an economically-minded chief operating officer (COO) may encourage a subordinate who is both a physician and manager to "think like a manager" (i.e., focus on enacting his identity as a manager and not his identity as a physician) when devising a budget since enacting the managerial identity is more economically-minded and organizationally-focused (e.g, Hoff, 1999). In contrast, a physician-manager may welcome the opportunity to enact both identities when devising the budget since he believes that doing so will ensure that both the organization's and the patients' best interests will be taken into consideration. 
Misalignment that occurs when the manager uses an exclusionary strategy for managing the subordinate's multiple identities, but the subordinate uses an inclusionary strategy, leads to resource suppression. LMX theory assumes that managers, as higher-status organizational members, have primary control over resource exchange in a manager subordinate-relationship (Farmer \& Aguinis, 2005; Graen \& Uhl-Bien, 1995). A subordinate's perception of managerial power also plays a role in shaping resource exchanges, especially when the manager does not verify the subordinate's identity claims (Farmer \& Aguinis, 2005). For instance, research on identity performance suggests that identity enactment can be constrained when policies and procedures threaten such enactment, such as those prohibiting open display of cultural memberships, beliefs, and preferences that do not conform to the corporate culture (e.g., Carbado \& Gulati, 1999; Creed \& Scully, 2000; Roberts \& Roberts, 2007). Managers play a key role in establishing and enforcing guidelines for identity enactment, as they "vigilantly monitor their workers' [identity performance] to determine whether they fit into the firm and buy into the firm's vision, policies, and practices" (Roberts \& Roberts, 2007: 373). Thus, a manager's exclusionary strategy may strongly discourage a subordinate from enacting valued work or non-work identities at work. LMX research characterizes this unbalanced exchange as an example of "negative reciprocity" in which the manager's preference prevails over a subordinate's desires (Sparrowe \& Liden, 1997). In the case of resource suppression, it is the manager's exclusionary preference that prevails over a subordinate's desire to enact multiple identities.

Thus, when a manager uses an exclusionary strategy and a subordinate uses an inclusionary strategy, misalignment signals and reinforces an identity's irrelevance at work, 
making knowledge and social capital associated with that particular identity less available for work-based tasks and activities.

This suggests the following proposition:

P1: If a manager uses an exclusionary strategy and a subordinate uses an inclusionary strategy for managing a subordinate's multiple identities, then resources associated with identities that the manager does not consider relevant to the work are likely to be suppressed in work-based tasks and activities.

Strategy misalignment and resource exploitation. We propose that a second form of strategy misalignment occurs when the scenario described in the previous section is reversed; a manager uses an inclusionary strategy, while the subordinate uses an exclusionary strategy for managing the subordinate's multiple identities. We label the resource utilization that arises from this form of misalignment "resource exploitation." A manager may use an inclusionary strategy when he or she believes that making certain subordinate identities relevant to the work may help attain managerial and/or organizational goals. In addition to research emphasizing the value-in-diversity hypothesis (e.g., Cox \& Blake, 1991), research on dual work identities also supports the idea that the enactment of multiple identities at work can yield outcomes that are beneficial to tasks and to others at work (Glynn, 2000; Hoff, 1999; Pratt \& Rafaeli, 1997). For example, enacting both physician and manager identities may enable physician-managers to persuade physicians working for a healthcare maintenance organization (HMO) that change in clinical practice is necessary for positive patient and economic outcomes (Hoff, 1999). Thus, an economically-minded COO may encourage a physician-manager to draw upon the knowledge and/or social capital associated with both identities to support the hospital's goals, particularly when they are aligned with goals that the manager values personally (e.g., meeting financial targets). 
Yet, organizational research proposes that some subordinates may avoid enacting certain identities at work because they believe that the performance of one identity may interfere with the performance of another identity at work (e.g., Clair, Beatty, \& Maclean, 2005; Ely, 1994; Hoff, 1999; Kreiner et al., 2006; Ladge et al., 2012). Hoff (1999) revealed how physician-managers with "profession-compatible" managerial identities viewed their role more in terms of protecting and serving physician interests rather than supporting HMO policies. These physician-managers also feared that other physician-managers would perceive them as disloyal to the profession when they enacted their managerial identities. As such, professional-compatible physician-managers often perceived conflicts between the enactment of their physician and managerial identities and chose to only enact their physician identities when interacting with other physicians (Hoff, 1999). Research on identity performance supports the notion that an individual may try to downplay or refrain from enacting certain identities in order to assimilate into the mainstream culture (Yoshino, 2002). ${ }^{2}$

This type of strategy misalignment can also ensue when managing a subordinate's non-work/work identity combination. For example, a manager may encourage a subordinate to use the knowledge and/or social capital associated with her racial, gender, and professional identities to support the organization's desire to engage more women of color as clients (Ely

\footnotetext{
${ }^{2}$ While it might appear that a subordinate's preference for excluding certain identities at work is evidence that he or she prefers not to be authentic at work, we view the subordinate's use of an exclusionary strategy in this example as a bounded form of authenticity (i.e., "strategic authenticity") rather than as a display of "inauthenticity" (Roberts et al., 2009). It is plausible that a subordinate who feels like he or she must exclude a part of who he or she is at work because of social/managerial expectations may feel inauthentic at work. However, another subordinate (like a physician-manager who chooses to exclude a managerial identity at work) may choose to exclude a part of who he or she is at work because he or she perceives that this strategy will be less detrimental to him or her. We are proposing that the former situation would likely lead to the resource suppression condition while the latter situation would likely lead to the resource exploitation condition.
} 
$\&$ Thomas, 2001). In contrast, the subordinate in this relationship may prefer not to be recognized as a "woman of color" at work in fear that others in the firm will attribute her success to racial or gender preferences instead of her professional competence (Bell, 1990; Ely, 1995). As such, the subordinate may prefer to use an exclusionary strategy, downplaying the relevance of her race/ethnicity and gender at work.

Despite the subordinate's preferences, he or she may still be pressured into enacting multiple identities at work. As described in our explanation of strategy misalignment and resource suppression, the power dynamics between managers and subordinates will likely subvert the subordinate's strategy for managing multiple identities. Despite the subordinate's preference for exclusion, a manager can coerce the subordinate into enacting multiple identities, particularly those that are considered valuable to work tasks and processes. "Resource exploitation" describes the resource utilization outcome that ensues when a manager's inclusionary strategy overpowers a subordinate's exclusionary strategy. Resource exploitation can occur when a manager persuades a subordinate to enact an identity that the subordinate prefers not to enact for the purpose of work-based tasks and activities (e.g., for organizational learning; Bryant, 2003; March, 1991; Vermeulen \& Barkema, 2001). Namely, fearing that he or she will be labeled as someone who is not a cooperative "team player" or will face retaliation from her manager, which may jeopardize her career advancement, a subordinate may comply with her manager's request to enact multiple identities. For instance, the physician-manager in the previous example may reluctantly provide the $\mathrm{COO}$ with information about which physicians are cooperating with new policies designed to limit referrals to expensive outside specialists (e.g., Grumbach, Osmond, Vranizan, Jaffe, \& Bindman, 1998), but only when he or she is specifically asked to do so. He or she may also 
share limited information about the organization's new policies with other physicians but may portray himself or herself as "the messenger" instead of as someone who believes in the actual message. Thus, the physician-manager is not using his or her physician-based social capital to persuade physicians to accept and adopt the new policies. Or, a woman of color may engage only with women of color clients or serve on a task force focused on engaging more women of color clients when he or she is specifically asked to do so. Resource exploitation is a second example of "negative reciprocity" highlighted in LMX research in which a manager's preference for inclusion prevails over a subordinate's desires for exclusion (Sparrowe \& Liden, 1997: 525). Our characterization of the resource exploitation condition reveals more about the source and manifestation of manager-subordinate misalignment.

This suggests the following proposition:

P2: If a manager uses an inclusionary strategy and a subordinate uses an exclusionary strategy for managing a subordinate's multiple identities, then resources associated with identities that the manager considers relevant to the work are likely to be exploited in work-based tasks and activities.

Strategy alignment and resource exchange. Strategy alignment, in contrast, occurs when a manager and a subordinate use similar strategies for managing a subordinate's multiple identities. We propose that one form of strategy alignment occurs when a manager and a subordinate both use exclusionary strategies. We label resource utilization that arises from this type of strategy alignment "resource exchange." In this condition, both a manager and a subordinate may believe that enacting certain identities during work-based tasks and activities creates undesirable consequences. For example, both a manager and a subordinate may prefer a color-blindness strategy to counter any perspectives that a subordinate has been given preferential treatment because of his or her race/ethnicity (Ely \& Thomas, 2001; Gallagher, 2003). A manager may be motivated to exclude the racial/ethnic identity to 
mitigate team conflict (Harrison et al., 1998) and the subordinate may be motivated to exclude the racial/ethnic identity to mitigate stigmatization (Ragins et al., 2007) or discriminatory treatment (Ellison et al., 2003). Notably, implicit or explicit agreement to exclude a subordinate's racial/ethnic identity can confirm the manager's and subordinate's construal of the subordinate as the ideal worker (Sanchez-Burks, 2002, 2004). Or, enacting a managerial identity as opposed to a physician identity can enhance one's credibility with a COO. In these respects, an agreement to exclude one or more of a subordinate's identities can be thought of as validation for both the manager's and the subordinate's hierarchically-based role identities as ideal boss and worker. Further, exclusionary strategies enable both a manager and a subordinate to validate the role identities that maintain the balance of power in the relationship and the status quo (cf. Farmer \& Aguinis, 2005: 1072).

We propose that a manager and a subordinate who feel that they share similar perspectives on managing the subordinate's multiple identities, and like each other more as a result, are more likely to exchange resources based on balanced reciprocity (Sparrowe \& Liden, 1997). Balanced reciprocity is characterized by immediate return and mutuality in resource exchange (Sparrowe \& Liden, 1997). As such, balanced reciprocity is substantively different from the negative reciprocity scenarios established in the resource suppression and resource exploitation conditions, in which a manager's preferences subvert his or her subordinate's.

Further, we propose that when a manager and subordinate both use an exclusionary strategy, the status quo is maintained which suggests that additional socio-emotional resources originating from the manager will be exchanged. Our theorizing is consistent with LMX theory's perspective on resource exchange which states that a manager may go beyond 
contractual, economic exchanges with subordinates and choose to exchange additional socioemotional resources such as trust with a subordinate who meets his or her expectations (Dulebohn et al., 2012; Sparrowe \& Liden, 2005). In turn, a subordinate will reciprocate with a high level of contribution that can enhance a manager's effectiveness (Sparrowe \& Liden, 2005). In this respect, agreeing to utilize an exclusionary strategy will maintain a balanced resource exchange dynamic that is typical of manager-subordinate relationships (e.g., Dulebohn et al., 2012; Graen \& Schiemann, 1978; Henderson et al., 2009; Tsui, Pearce, Porter, \& Tripoli, 1997). Notably, the manager and subordinate will continue to exchange resources with one another that typify their roles in the relationship (e.g., Adler \& Kwon, 2002; Alvesson, 2004; Cropanzano \& Mitchell, 2005; Liden \& Graen, 1980; Tsui et al., 1997) including role-related knowledge (Alvesson, 2001, 2004) and social capital (Adler \& Kwon, 2002) for support and trust (e.g., Cropanzano \& Mitchell, 2005; Tsui et al., 1997).

This suggests the following proposition:

P3: If a manager and a subordinate both use exclusionary strategies to manage a subordinate's multiple identities, then only the resources associated with the role identities each considers important at work are likely to be exchanged in work-based tasks and activities.

Strategy alignment and resource production. A second form of strategy alignment occurs when a manager and a subordinate both use inclusionary strategies for managing the subordinate's multiple identities. We label resource utilization that arises from this form of strategy alignment "resource production." Resource production is characterized by the mutual investment of resources including those previously unused or underutilized in order to generate new resources. For instance, a manager and a subordinate may both believe that making more of the subordinate's identities relevant to the work may lead to positive outcomes for the organization. In this case, a hospital COO may believe that encouraging a 
physician-manager to enact both physician and managerial identities may help the hospital attain growth goals (Hoff, 1999). Likewise, a physician-manager may also believe that enacting both identities will allow her to communicate the hospital's new strategy of growth effectively to the physicians in her department, while at the same time providing the physician-manager with the opportunity to promote ideas that are aligned with her physician identity. Or, a manager may encourage a subordinate who is a woman of color to utilize the social capital associated with her racial, gender, and professional identities to attract more women of color clients to the firm. A subordinate may view the knowledge and social capital she has gained from being a woman of color as valuable to the team, and may wish to utilize these resources in work-based tasks and activities (Ely \& Thomas, 2001). As such, an explicit agreement to make both of the subordinate's identities relevant to his or her work-based tasks and activities enables a manager and a subordinate to use the subordinate's identity-based knowledge and/or social capital and the manager's role-related resources to help further the organization's values around growth and innovation (Cox \& Blake, 1991; Ely \& Thomas, 2001). Thus, we predict that an agreement to make more of the subordinate's identities relevant to work-based tasks and activities can enable a manager and a subordinate to produce new work resources.

Previous research has proposed that resource production emerges from resource exchange, in that effectively deploying available resources enables scarce and valued new resources to be produced (Fredrickson, 2003; Rousseau \& Ling, 2007). Our theorizing further develops these claims by proposing how resource production occurs through a three-stage (though not necessarily linear) process of heedful interrelating (e.g., individuals being attentive to how their actions affect the functioning of the system; Weick \& Roberts, 1993). 
In this respect, we acknowledge that there are multiple resource "exchanges" between a manager and his/her subordinate that lead to the production of new resources in a resource production condition: 1) exchanging existing resources, 2) combining a manager's and a subordinate's resources, and 3) production of new resources. In the first phase, the manager and subordinate decide to make more of the subordinate's identities relevant to work-based tasks and activities. Building on the resource exchange condition, a manager indicates that he or she trusts a subordinate (i.e., manager providing a socio-emotional resource to a subordinate) to enact his or her multiple identities in ways that support the organization's growth and innovation goals (i.e., goals that the manager personally values), and, in turn, a subordinate may reciprocate with a high level of effort that can enhance the organization's effectiveness (Sparrowe \& Liden, 2005). For example, a physician-manager proposes an idea to the hospital $\mathrm{COO}$ for a new patient care program that could be both patient-centered and cost-effective, and is aligned with the hospital's growth goals. The COO likes the idea and encourages the physician-manager to develop it further by developing a proposal that reflects considerations for both managerial and patient-care outcomes. As with the resource exchange condition, an agreement to use similar strategies to manage a subordinate's multiple identities establishes or reinforces some degree of similarity between a subordinate and his manager, which may facilitate liking in the relationship (Phillips \& Bedeian, 1994).

In the second stage, the physician-manager's knowledge is combined with the COO's resources (Baker \& Dutton, 2007). For example, the COO uses his or her social capital to garner support from other senior leaders for the physician-manager's proposal. Hence, both individuals invest resources from their respective resource pools (e.g., Hobfoll, 1989; Hobfoll, 2011). Thus, not only does the knowledge that stems from physician-manager's physician 
and managerial identities being enacted simultaneously serve as the raw material for resource production, but the manager and the subordinate continue to exchange economic and socioemotional resources (Rousseau \& Ling, 2007).

In the third stage, new interpretations and new discoveries are generated (Cox \& Blake, 1991; Ely \& Thomas, 2001; Jordan et al., 1991). For example, the proposal sparks an idea for another patient care program sponsored by a different senior leader in which the COO and the physician-manager are asked to take part in developing. The dynamics in stage three exemplify a type of generalized reciprocity in which learning, new work resources, and collaborative practices arise from the combination and recombination of resources in a community or network (Baker \& Dutton, 2007).

Hence, unlike situations in which resource utilization is characterized by the exchange of resources originating from and being dominated by a manager, resource production is characterized by the investment of previously unused or underutilized resources and their combination with other existing resources to generate new resources. Thus, we contend that resources can only be produced by the mutual investment of resources and in resource generation activities.

This suggests the following proposition:

P4: If a manager and a subordinate both use inclusionary strategies for managing a subordinate's multiple identities, then new resources are likely to be produced in work-based tasks and activities.

\section{Resource Utilization and the Quality of the Manager-Subordinate Relationship}

In this section, we predict that resource utilization will lead to three different types of manager-subordinate relationships: low-quality, social exchange, and generative. 
We examine each of these relationships in terms of three characteristics: perceived contribution of resources, psychological safety, and mutual growth-in-connection. Perceived contribution of resources refers to each person's perspective on the extent to which the other is contributing sufficient or expected resources to the relationship (e.g., Dienesch \& Liden, 1986). Psychological safety refers to the belief that an individual can be open, authentic, and direct in a particular setting or role (Edmondson, 1999; Nembhard \& Edmondson, 2011). Finally, mutual growth-in-connection reflects mutual empathy and mutual empowerment, including an experience of zest, empowered action, increased sense of worth, new knowledge, and desire for more connection from resource utilization (Jordan et al., 1991; Miller \& Stiver, 1997).

\section{Resource suppression and a low-quality manager-subordinate relationship. We}

propose that resource suppression will create a low-quality manager-subordinate relationship. Past research characterizes low-quality manager-subordinate relationships by a lack of perceived mutuality in the relationship (Dienesch \& Liden, 1986) and a reliance on the economic exchange specified in the contractual employment agreement (Goodwin, Bowler, \& Whittington, 2009) such as pay for performance (Blau, 1964; Dulebohn et al., 2012; Lin, 2002). Notably, resource suppression reinforces the manager's control over resources in the relationship, strengthening the status hierarchy (Emerson, 1962; Farmer \& Aguinis, 2005; Graen \& Uhl-Bien, 1995), and the subordinate's dependence on the manager for work-related resources (Emerson, 1962; Farmer \& Aguinis, 2005). Because the contractual agreement is maintained in the resource suppression condition, and the manager maintains control of the resource use, it is likely that the manager will perceive that each person is contributing his or her share of agreed upon resources to the relationship. However, the subordinate may still 
feel dissatisfied because he or she is unable to contribute certain resources that he or she would like to invest in work-based tasks and activities. Because of this dynamic, the subordinate may perceive that their contribution to the exchange is unequal because their resources are undervalued and because the manager is not helping him or her to achieve his or her work goals (Dienesch \& Liden, 1986). Then, it is possible that a subordinate whose personally valued resources have been suppressed will engage less at work, which can affect his or her performance (Kahn, 1990; Kahn, 2007). It is also possible that a subordinate might remain engaged at work but only in a contractual way. In accordance with LMX theory, we postulate that these contractual manager-subordinate relationships will be low quality relationships (Graen \& Uhl-Bien, 1995).

Further, we propose that the exclusion of a valued identity and suppression of valued resources can inhibit a subordinate's sense of psychological safety in the relationship with his or her manager, which is the belief that he or she can be open, authentic, and direct in the relationship (Edmondson, 1999; Nembhard \& Edmondson, 2011). Research suggests that subordinates may feel less psychologically safe at work particularly when they feel powerless (Nembhard \& Edmondson, 2011; Nembhard \& Edmondson, 2006), where "powerlessness" refers to "an absence of the necessary means--the skills, authority, credibility, autonomy, opportunities for participation, resources, and so forth--to cope with task demands and to influence events that directly affect one" (Ashforth, 1994: 762). When a subordinate is encouraged not to enact his or her desired identity, and the identity-related resources that he or she would like to contribute are suppressed, a subordinate may feel that he or she does not have the power to be open and authentic with his or her manager. In this respect, resource suppression enhances a subordinate's sense of powerlessness and dependence, which makes 
the subordinate feel less psychologically safe in the relationship. According to research on psychological safety, low quality relationships are marked by differences in the sense of psychological safety between persons in the relationship (Nembhard \& Edmondson, 2011).

Finally, we propose that the exclusion of a valued identity and suppression of valued resources inhibits mutual growth-in-connection (Jordan et al., 1991; Miller \& Stiver, 1997). Growth-in-connection occurs from increasing one's proficiency in connecting to others which is achieved through mutual empathy (i.e., feeling and thinking something similar to what another person thinks and feels) and mutual empowerment (i.e., each person in the relationship is empowered) (Jordan et al., 1991). However, a lack of mutual empathy is evident in the case of resource suppression given that the manager's and subordinate's strategies for managing the subordinate's multiple identities are misaligned. Further, resource suppression disempowers a subordinate because he or she is unable to contribute certain resources that he or she would like to invest in work-based tasks and activities.

LMX theory posits that only one individual in the relationship needs to perceive that the relationship is low-quality in order for the relationship to be a low-quality relationship (Graen \& Uhl-Bien, 1995). That is, a manager-subordinate relationship is low-quality when at least one individual in the relationship perceives that it is low-quality or perceptions of relational quality are not shared. Thus, we contend that the subordinate's negative perception of resource contribution and psychological safety and lack of mutual growth-in-connection in the resource suppression condition makes the relationship a low-quality relationship. Notably, LMX research frequently measures relational quality from the subordinate's perspective (Dulebohn et al., 2012; Gerstner \& Day, 1997). Therefore, given that resource suppression creates for a subordinate the perception that there is an unequal contribution of 
resources due to underutilization of his or her identity-based resources in the relationship, since a subordinate's sense of psychological safety is negatively affected in the dynamic, and since there is a lack of mutual growth-in-connection, we propose that resource suppression will lead to a low-quality relationship. This suggests the following proposition:

P5: If resources associated with at least one of a subordinate's multiple identities are suppressed in a manager-subordinate relationship, then the relationship is likely to be a low-quality relationship.

\section{Resource exploitation and a low-quality manager-subordinate relationship. We}

propose that resource exploitation will also create a low-quality manager-subordinate relationship characterized by a lack of perceived mutuality in the relationship (Dienesch \& Liden, 1986) and a reliance on the economic exchange specified in the contractual employment agreement (Goodwin et al., 2009). Like resource suppression, resource exploitation also reinforces the status hierarchy in the relationship and the manager's control over the instrumental exchange of resources (Emerson, 1962; Farmer \& Aguinis, 2005; Graen \& Uhl-Bien, 1995). Again, the manager may perceive that each person is contributing sufficient resources to the relationship. Yet, the subordinate may feel he or she is contributing resources that were not part of the original employment contract (Dienesch \& Liden, 1986; Liden \& Graen, 1980). Notably, resource exploitation provides a manager with additional resources, but a subordinate likely feels that the resource exchange is unequal. In spite of the subordinate's investment of identity-related resources in the relationship, he or she does not gain valued resources in exchange for that additional input. For example, the subordinate may not receive additional financial or socio-emotional rewards in exchange for investing additional identity-related knowledge in the work. Ely and Thomas (2001) found that black employees working in a financial services department that serviced predominantly black 
banking clientele were not able to contribute as much to their firm nor were they able to gain as much recognition as their white counterparts who worked with white banking clientele. Since the subordinate's perceived work-related needs are not being met, his or her resources are being exploited. Like the resource suppression condition, it is possible that a subordinate whose resources have been exploited might remain engaged at work but only in a contractual way. As such, the relationship that ensues from resource exploitation is a low-quality relationship. We also propose that resource exploitation negatively affects a subordinate's sense of psychological safety in the manager-subordinate relationship (Edmondson, 1999; Nembhard \& Edmondson, 2011). Recall that a subordinate in the resource exploitation condition may prefer to exclude part of who he or she is at work because he or she feels that exclusion will benefit him or her personally (i.e., exhibiting strategic authenticity; Roberts et al., 2009). We propose that resource exploitation reduces a subordinate's sense of authenticity by compelling him or her to behave contrary to his or her identity management preferences. Such subjugation of identity preferences can enhance a subordinate's feelings of powerlessness, which signals that he or she does not feel psychological safe in the managersubordinate relationship (Ashforth, 1994; Nembhard \& Edmondson, 2011; Nembhard \& Edmondson, 2006).

Finally, as with resource suppression, we propose that resource exploitation also inhibits mutual growth-in-connection including mutual empathy and mutual empowerment (Jordan et al., 1991; Miller \& Stiver, 1997). In particular, a lack of mutual empathy is also evident in the case of resource exploitation given that the manager's and subordinate's strategies for managing the subordinate's multiple identities are also misaligned in this scenario. Resource exploitation also disempowers a subordinate because he or she is unable 
to resist contributing certain resources that he or she would not like to invest in work-based tasks and activities.

Given that resource exploitation creates a perception for the subordinate that he or she is contributing more resources to the relationship than he or she desires, reduces a subordinate's sense of psychological safety in the manager-subordinate relationship, and inhibits mutual growth-in-connection, we propose that resource exploitation will lead to a low-quality relationship. This suggests the following proposition:

P6: If resources associated with at least one of a subordinate's multiple identities are exploited in a manager-subordinate relationship, then the relationship is likely to be a low-quality relationship.

\section{Resource exchange and a social exchange manager-subordinate relationship. In}

contrast, we propose that resource exchange will create a social exchange managersubordinate relationship. Social exchange relationships are frequently characterized by feelings of liking and reciprocity (Dienesch \& Liden, 1986; Graen \& Schiemann, 1978; Graen \& Uhl-Bien, 1995). Notably, when a manager and a subordinate both use exclusionary strategies to manage a subordinate's multiple identities, they establish or reinforce some degree of similarity between them. Specifically, LMX theory defines social exchange relationships according to perceived mutuality in the relationship (Dienesch \& Liden, 1986) which is measured by reciprocity in the exchange of resources (Sparrowe \& Liden, 1997). Social exchange relationships are viewed both as instrumental and social in nature (i.e., defined by behaviors such as helping, listening, discussing non-work-related topics, offering advice; Goodwin et al., 2009; Lin, 2002).

We propose that resource exchange also reinforces the subordinate's resource dependence in the relationship, but this may not be concerning to a subordinate who prefers to 
exclude one or more of his identities (and associated resources) from work-based tasks and activities. This social exchange relationship fulfills and reinforces the resource expectations of each party. As such, resource exchange can create the perception that each person is making an equal contribution to the relationship because both parties are contributing resources that relate specifically to their roles. Further, because of the perceived similarity in values related to identity enactment, managers may invest additional socioeconomic resources in the subordinates with whom they have aligned identity management strategies (Phillips \& Bedeian, 1994). For instance, a manager and a subordinate may share the same perspective on what it means to be an "ideal worker" such that ideal workers should exclude non-work identities while at work (Costello, 2005; Ramarajan \& Reid, 2013). This believed similarity may lead a manager to put forth more effort and time in mentoring a subordinate who chooses to exclude non-work identities while at work.

Resource exchange also promotes psychological safety in the manager-subordinate relationship, or the belief that both individuals can be open, authentic, and direct in their formal roles (Edmondson, 1999; Nembhard \& Edmondson, 2011; Scandura \& Pellegrini, 2008). When formal roles are maintained, identities attached to those roles are verified and the balance of power in the relationship persists. Thus, resource exchange enables both a manager and a subordinate to enact and maintain the current power and status hierarchy. In this case, a manager can be open, authentic, and direct in his or her role as an ongoing source of resources in the relationship and a subordinate can be open, authentic, and direct as the person in the relationship who depends on a manager for resources. As such, an agreement to enact and maintain a clear power and status hierarchy can promote psychological safety for both individuals, making the relationship a social exchange relationship. 
Yet, we propose that resource exchange does not promote mutual growth-inconnection (Jordan et al., 1991; Miller \& Stiver, 1997). While resource exchange may promote mutual empathy, given that strategies for managing a subordinate's multiple identities are aligned (i.e., feeling and thinking something similar to what another person thinks and feels), and positive affective outcomes including an increased sense of worth, it falls short of generating new knowledge in the relationship and empowered action (i.e., putting into practice what was learned in the interaction) given that the status quo is maintained. As a result, only three of the five criteria for mutual growth-in-connection are met in a resource exchange condition.

Extant LMX research posits that a manager-subordinate relationship is high-quality when resource exchange is balanced (Cogliser, Schriesheim, Scandura, \& Gardner, 2009; Paglis \& Green, 2002). Hence, given that resource exchange creates a shared perception of mutuality in terms of expectations for resource contribution, a shared sense of psychological safety in a manager-subordinate relationship, but does not promote mutual growth-inconnection, we propose that resource exchange will lead to a social exchange relationship. This suggests the following proposition:

P7: If resources related specifically to manager and subordinate roles are exchanged in a manager-subordinate relationship, then the relationship is likely to be a social exchange relationship.

\section{Resource production and a generative manager-subordinate relationship. We}

propose that resource production will create a generative manager-subordinate relationship.

Generative relationships have been discussed in RCT (e.g., Jordan et al., 1991; Miller, 1986;

Miller \& Stiver, 1997) and research utilizing a POS lens on positive workplace relationships (e.g., Dutton \& Heaphy, 2003; Dutton \& Ragins, 2007; Rousseau \& Ling, 2007). In the field 
of organizational studies, these relationships have also been called, "positive relationships at work" (Dutton \& Ragins, 2007) and "positive organizational relationships" (Rousseau \& Ling, 2007), but we use the label "generative relationships" in this paper in order to afford easier comparison to low-quality and social exchange manager-subordinate relationships.

Generative relationships are enhanced social exchange relationships. These relationships utilize resources that originate from both the manager and a subordinate, but they also produce new resources that are particularly scarce and valued (Rousseau \& Ling, 2007). In doing so, they also enable existing resources to be combined, which can alter their meaning, function, and value (Rousseau \& Ling, 2007; Glynn \& Wrobel, 2007). Additionally, a manager and a subordinate in a generative manager-subordinate relationship feel psychologically safe in their relationship with each other. Hence, in a generative relationship, both a manager and a subordinate perceive that the relationship is positive.

Yet, building on RCT and a POS perspective on positive relationships at work, we suggest that generative relationships are unique from social exchange relationships discussed within LMX theory. In generative manager-subordinate relationships, managers and subordinates both invest resources from their respective resource pools in ways that go beyond the contractual, economic based employment relationship and the exchange of socioemotional resources initiated by the manager. Further, managers and subordinates in generative relationships both experience mutual growth-in-connection from their social interactions (e.g., Jordan et al., 1991; Miller, 1976; Miller \& Stiver, 1997) and behave authentically (Leroy, Anseel, Gardner, \& Sels, 2012). Specifically, both a manager and a subordinate in a generative relationship experience a greater sense of zest or a feeling of increased vitality, aliveness, and energy that arises from connecting to one another at work. 
They are motivated to act in the moment and experience an increased sense of worth since each person recognizes and acknowledges that the other's experiences are valuable to workbased tasks and activities. Further, since both a manager and a subordinate learn and feel empowered from having created new knowledge in their interaction, they may both desire more connection with the other person and to establish similar connections with others at work (Baker \& Dutton, 2007; Dutton \& Heaphy, 2003; Miller \& Stiver, 1997). In essence, resource production gives a manager and a subordinate new ways of seeing (Carlsen \& Dutton, 2011; Miller, 1976) and creates an overall experience of generativity for both individuals (i.e., "experience[s] that bring a feeling of energy and aliveness to people and also have the potential to produce more enduring expansive and transformative consequences"; Carlsen \& Dutton, 2011: 15).

This suggests our final proposition:

P8: If new resources are produced in a manager-subordinate relationship, then the relationship is likely to be a generative relationship.

\section{DISCUSSION}

We have presented a variance-based model of how the misalignment or alignment of strategies that a manager and a subordinate use for managing a subordinate's multiple identities affects resource utilization and the quality of the manager-subordinate relationship. This model integrates and extends several perspectives on relationships in organizations, demonstrates how identities are important sources of resources at work, and enriches our understanding of the role that a subordinate's resources can play in manager-subordinate relationships. Here, we discuss how these contributions open pathways for future research 
and propose an agenda that offers ideas for how to extend our theory. We also discuss the practical implications of our model.

\section{Managing Multiple Identities at Work}

Our emphasis on managing a subordinate's multiple identities addresses gaps in LMX, leadership, and identity literatures. Specifically, the LMX and leadership literatures are beginning to examine managers' and subordinates' identities as key variables in managersubordinate relationships (e.g., Chang \& Johnson, 2010; Jackson \& Johnson, 2012; Leroy et al., 2012). For example, Leroy and colleagues (2012) found that authentic leadership (i.e., enacting one's “true self” in a leader role) and authentic followership (i.e., enacting one's "true self" in a follower role) coproduce follower need satisfaction and work role performance. Our model builds upon and differs from extant LMX, leadership, and identity theory in that we emphasize the influence of identity management on the quality of the relationship more holistically and not just on individual outcomes (i.e., effect of leader and follower authenticity on follower satisfaction and performance, cf., Leroy et al., 2012). In doing so, we extend the understanding of antecedents to high-quality relationships from individual-level personal characteristics to relational behavior.

Several aspects of our theorizing provide a foundation for new research on managing multiple identities at work. Building on DeRue and Ashford (2010) who theorize around the mutual construction of leaders' and followers' roles and identities, an important extension of our model would be to examine how the mutual management of both individuals' multiple identities in the relationship affects the quality of the relationship (i.e., a $2 \times 2 \times 2$ matrix of multiple identity management). Such a model would be conceptually complex. Yet, our paper has laid the groundwork for further examination of alignment and misalignment of managers' 
and subordinates' strategies for managing their own and others' identities. An empirical investigation using narrative techniques (e.g., Maitlis, 2009) could provide information about the series of events that affect multiple identity management strategies for each person in the dyad and would aid in generating a set of testable hypotheses. These hypotheses could then be examined through a field study of manager-subordinate dyads (cf., Cogliser et al., 2009; Paglis \& Green, 2002), using a survey that combines existing measures with those developed through the qualitative study to capture both individuals' views of their multiple identity management strategies, resource dynamics, and the quality of their relationship. By conducting this type of mixed-methods investigation, scholars would be able to generate a more robust understanding of multiple identity management, resource dynamics, and the quality of manager-subordinate relationships from a dyadic perspective.

\section{Resource Utilization}

A second area of contribution is our model's discussion of resource utilization. While previous research has demonstrated a link between identity enactment and resource availability in organizations (Callero, 1994; Thoits, 1983), our model enriches this perspective by addressing how resources are used and even generated within manager-subordinate interactions. Further, in theorizing around four different scenarios for managing a subordinate's multiple identities, we contribute to the growing body of identity and diversity scholarship interested in understanding identities as potentially valuable sources of resources for work-based tasks and activities (e.g., Caza \& Wilson, 2009; Creary, Caza, \& Roberts, forthcoming; Dutton, Roberts, \& Bednar, 2010; Ely \& Thomas, 2001; Fitzsimmons, 2013). We build on and extend this line of theorizing to propose several ways in which subordinatebased and identity-related resources are affected within manager-subordinate relationships. In 
particular, our model emphasizes the role of relationships in making identity-related resources available — notably, the role that hierarchical relationships and associated power dynamics play in suppressing or exploiting these resources, or using these resources to exchange or produce other resources.

At the same time, it is not our intention to suggest that all identities can provide access to useful resources or that all resources are useful in the workplace. An interesting empirical study would be to investigate which identities (beyond the broad categories of "work" and "non-work" identities") have the potential to lead to new resources when those identities are included at work. Further, collective endorsement (or lack thereof) of individuals' multiple identities may affect the utilization of related resources at work (cf., DeRue \& Ashford, 2010). For example, whether other members of a subordinate's department collectively view the subordinate's racial or ethnic identity as an asset to their department can affect whether the knowledge and/or social capital resources associated with the racial or ethnic identity are utilized at work (cf., Ely \& Thomas, 2001; Polzer et al., 2002). While it is clear from past research that dynamics within a collective can affect identity management and resource utilization, future work needs to test our theoretical model with different types of identities, among dyads and collectives, to examine these relationships more specifically.

\section{Quality of Manager-Subordinate Relationships}

Finally, in combining insights from POS, RCT, and LMX theory, we broaden our understanding of the quality of manager-subordinate relationships. Specifically, we examine them in terms of three indicators commonly cited in research on the quality of relationships at work: perceived contribution of resources, psychological safety, and mutual growth-inconnection. In so doing, we differentiate between low-quality relationships, social exchange 
relationships (e.g., Dulebohn et al., 2012; Graen \& Uhl-Bien, 1995; Liden, Wayne, \& Stilwell, 1993), and generative relationships (Dutton \& Heaphy, 2003; Dutton \& Ragins, 2007; Jordan et al., 1991). Our research illustrates that "positivity" is not uni-dimensional when it comes to manager-subordinate relationships. Our differentiation of social exchange relationships and generative relationships is particularly noteworthy since scholars consider both to be "positive relationships" without systematic explanation of their similarities and differences (Dutton \& Ragins, 2007; Sparrowe \& Liden, 1997). Notably, our research does not aim to suggest that one type of positive work relationship is "better" than another. Rather, in identifying two types of positive manager-subordinate relationships, we illustrate how different types of positive manager-subordinate relationships can serve different purposes for the individuals in them and for their organizations. Future research should consider the role

of the organizational context in fostering social exchange versus generative relationships. Are certain types of organizations more likely to encourage generative practices in managersubordinate relationships than others (cf., Brickson \& Brewer, 2001; Sonenshein, 2014)?

\section{Limitations}

A limitation of our theorizing is that we do not fully account for the role that motives play in managing a subordinate's multiple identities including those motives that are "lessthan-noble." For example, by allowing race to be a factor in his or her attitudes and behavior toward people, a racist manager would include a subordinate's racial identity at work. A subordinate who knows that her manager is racist may prefer to exclude her racial identity at work. In this case, their strategies would be misaligned given that the racist manager is actually paying attention to the subordinate's racial identity (inclusionary strategy) for "lessthan-noble" reasons even while the subordinate is trying to downplay race (exclusionary 
strategy). While we would predict that their relationship would be low quality for a number of reasons, we also acknowledge that a resource utilization dynamic that we have not predicted may ensue. For example, a racist manager may withhold resources from a subordinate of a different race and, instead, provide those resources to subordinates that share his or her same race. Resource withholding is not one of the four resource utilization conditions that we have elaborated in our theory building. In light of this discussion, we do hope that future research will focus specifically on the role that motives play in the relationships that we have predicted.

\section{Practical Implications}

Many organizational leaders espouse that the key to being competitive in the current global environment is to utilize the knowledge and/or social capital associated with employees' diverse backgrounds as a resource for organizations in which they work. As organizational strategists acknowledge that individuals' identities are multiple and multifaceted (Ely \& Thomas, 2001; Hoff, 1999; Sambrook, 2006), they are also more likely to recognize that being known, understood, and valued for one's multiple identities is a key to workplace effectiveness. Yet, bringing one's whole self to work could potentially yield negative consequences for individuals (Rudman, 1998) and groups (Dumas, Rothbard, \& Phillips, 2008) at work. As such, the practice of recognizing and acknowledging multiple identity dynamics at work can expand the understanding of how identities, resources, and the quality of relationships constitute one another at work.

\section{CONCLUSION}

We have drawn upon theories of identity management (e.g., Dutton et al., 2010; Ramarajan \& Reid, 2013; Roberts \& Creary, 2011) and relationships (e.g., Dutton \& Heaphy, 
2003; Dutton \& Ragins, 2007; Graen \& Uhl-Bien, 1995; Miller \& Stiver, 1997) to offer a theoretical model explaining the effect of managing a subordinate's multiple identities on resource utilization and the quality of a manager-subordinate relationship. We encourage additional conceptual and empirical inquiry that helps scholars further understand the nature of identity management and relational outcomes, as well as further investigations of other mechanisms beyond resource utilization that may explain this linkage. 


\section{REFERENCES}

Acker, J. 1990. Hierarchies, jobs, bodies: A theory of gendered organizations. Gender \& Society, 4(2): 139-158.

Adler, P. S., \& Kwon, S.-W. 2002. Social capital: Prospects for a new concept. Academy of Management Review, 27(1): 17-40.

Agarwal, U. A., Datta, S., Blake-Beard, S., \& Bhargava, S. 2012. Linking LMX, innovative work behaviour and turnover intentions: the mediating role of work engagement. Career Development International, 17(3): 208-230.

Alvesson, M. 2001. Knowledge work: Ambiguity, image and identity. Human Relations, 54(7): 863-886.

Alvesson, M. 2004. Knowledge work and knowledge-intensive firms: Oxford University Press.

Ashforth, B. 1994. Petty tyranny in organizations. Human Relations, 47(7): 755-778.

Ashforth, B. E. 2001. Role transitions in organizational life. Mahwah, NJ: Lawrence Erlbaum Associates, Inc.

Baker, W., \& Dutton, J. E. 2007. Enabling positive social capital in organizations. In J. Dutton, \& B. Ragins (Eds.), Exploring positive relationships at work: Building a theoretical and research foundation: 325-345. New York: Lawrence Erlbaum \& Associates.

Bell, E. L. 1990. The bicultural life experience of career-oriented black women. Journal of Organizational Behavior, 11: 459-477. 
Blake-Beard, S. D., \& Roberts, L. M. 2004. Releasing the double bind of visibility for minorities in the workplace: Boston: Center for Gender in Organizations, Simmons School of Management.

Blau, P. M. 1964. Exchange and power in social life. New Jersey: Transaction Publishers.

Brickson, S., \& Brewer, M. 2001. Identity orientation and intergroup relations in organizations. In M. Hogg, \& D. J. Terry (Eds.), Social Identity Processes in Organizational Contexts: 49-66. Philadelphia: Psychology Press.

Bryant, S. E. 2003. The role of transformational and transactional leadership in creating, sharing and exploiting organizational knowledge. Journal of Leadership \& Organizational Studies, 9(4): 32-44.

Burke, P. J. 1980. The self: Measurement requirements from an interactionist perspective. Social Psychology Quarterly: 18-29.

Callero, P. L. 1994. From role-playing to role-using: Understanding role as resource. Social Psychology Quarterly: 228-243.

Cantor, N., \& Mischel, W. 1979. Prototypes in person perception, Advances in Experimental Social Psychology, Vol. 12: 3-52. New York: Academic Press, Inc.

Carbado, D. W., \& Gulati, M. 1999. Working identity. Cornell L. Rev., 85: 1259.

Carlsen, A., \& Dutton, J. E. 2011. Research alive: Exploring generative moments in doing qualitative research. Portland, OR: Copenhagen Business School Press.

Caza, B. B., \& Wilson, M. G. 2009. Me, myself, and I: The benefits of work-identity complexity. In L. M. Roberts, \& J. E. Dutton (Eds.), Exploring positive identities and organizations: Building a theoretical and research foundation 99-123. New York, NY: Routledge Taylor and Francis Group. 
Chang, C.-H. D., \& Johnson, R. E. 2010. Not all leader-member exchanges are created equal: Importance of leader relational identity. The Leadership Quarterly, 21(5): 796-808.

Chatman, J. A., Polzer, J. T., Barsade, S. G., \& Neale, M. A. 1998. Being different yet feeling similar: The influence of demographic composition and organizational culture on work processes and outcomes. Administrative Science Quarterly, 43(4): 749-780.

Cialdini, R. B. 1989. Indirect tactics of image management: Beyond basking. In R. A. Giacolone, \& P. Rosenfeld (Eds.), Impression management in the organization, Vol. 45: 45-56. Hillsdale, NJ: Lawrence Erlbaum Associates.

Clair, J. A., Beatty, J., \& Maclean, T. 2005. Out of sight but not out of mind: Invisible social identities in the workplace. Academy of Management Review, 30: 78-95.

Cogliser, C. C., Schriesheim, C. A., Scandura, T. A., \& Gardner, W. L. 2009. Balance in leader and follower perceptions of leader-member exchange: Relationships with performance and work attitudes. The Leadership Quarterly, 20(3): 452-465.

Costello, C. Y. 2005. Professional identity crisis: Race, class, gender, and success at professional schools. Nashville, TN: Vanderbilt University Press.

Cox, T. H., \& Blake, S. 1991. Managing cultural diversity: Implications for organizational competitiveness. Academy of Management Executive, 5(3): 45-56.

Creary, S. J., Caza, B. B., \& Roberts, L. M. forthcoming. Out of the box? How managing a subordinate's multiple identities affects the quality of a manager-subordinate relationship. Academy of Management Review.

Creed, W. D., \& Scully, M. A. 2000. Songs of Ourselves: Employees' Deployment of Social Identity. Journal of Management Inquiry, 9(4): 391-412. 
Crisp, R. J., Turner, R. N., \& Hewstone, M. 2010. Common ingroups and complex identities: Routes to reducing bias in multiple category contexts. Group dynamics: Theory, research, and practice, 14(1): 32 .

Cropanzano, R., \& Mitchell, M. S. 2005. Social exchange theory: An interdisciplinary review. Journal of Management, 31(6): 874-900.

Dansereau, F., Graen, G., \& Haga, W. J. 1975. A vertical dyad linkage approach to leadership within formal organizations: A longitudinal investigation of the role making process. Organizational behavior and human performance, 13(1): 46-78.

DeRue, D. S., \& Ashford, S. J. 2010. Who will lead and who will follow? A social process of leadership identity construction in organizations. Academy of Management Review, 35(4): 627-647.

Dienesch, R. M., \& Liden, R. C. 1986. Leader-member exchange model of leadership: A critique and further development. Academy of Management Review: 618-634.

Dulebohn, J. H., Bommer, W. H., Liden, R. C., Brouer, R. L., \& Ferris, G. R. 2012. A metaanalysis of antecedents and consequences of leader-member exchange integrating the past with an eye toward the future. Journal of Management, 38(6): 1715-1759.

Dumas, T. L., Rothbard, N. P., \& Phillips, K. W. 2008. Self-disclosure: Beneficial for cohesion in demographically diverse work groups? Research on Managing Groups and Teams, 11: 143-166.

Dutton, J. E., \& Heaphy, E. D. 2003. The power of high-quality connections. In K. S. Cameron, J. E. Dutton, \& R. E. Quinn (Eds.), Positive Organizational Scholarship: Foundations of a New Discipline: 263-278. San Francisco: Berrett-Koehler Publishers, Inc. 
Dutton, J. E., \& Ragins, B. R. 2007. Exploring positive relationships at work: Building a theoretical and research foundation. New York: Lawrence Erlbaum Associates.

Dutton, J. E., Roberts, L. M., \& Bednar, J. 2010. Pathways for positive identity construction at work: Four types of positive identity and the building of social resources. Academy of Management Review, 35: 265-293.

Edmondson, A. 1999. Psychological safety and learning behavior in work teams. Administrative Science Quarterly, 44(2): 350-383.

Ellison, M. L., Russinova, Z., MacDonald-Wilson, K. L., \& Lyass, A. 2003. Patterns and correlates of workplace disclosure among professionals and managers with psychiatric conditions. Journal of Vocational Rehabilitation, 18(1): 3-13.

Ely, R. 1995. The power in demography: Women's social constructions of gender identity at work. Academy of Management Journal, 38(3): 589-634.

Ely, R. J. 1994. The effects of organizational demographics and social identity on relationships among professional women. Administrative Science Quarterly, 39(2): 203-238.

Ely, R. J., \& Thomas, D. A. 2001. Cultural diversity at work: The effects of diversity perspectives on work group processes and outcomes. Administrative Science Quarterly, 46(2): 229-273.

Emerson, R. M. 1962. Power-dependence relations. American Sociological Review, 27(1): 31-41.

Emerson, R. M. 1976. Social exchange theory. Annual review of sociology: 335-362.

Erikson, E. H. 1993. Childhood and society: WW Norton \& Company. 
Fadil, P. A. 1995. The effect of cultural stereotypes on leader attributions of minority subordinates. Journal of Managerial Issues: 193-208.

Farmer, S. M., \& Aguinis, H. 2005. Accounting for subordinate perceptions of supervisor power: an identity-dependence model. Journal of Applied Psychology, 90(6): 1069.

Ferdman, B. M., \& Roberts, L. M. 2013. Creating inclusion for oneself: Knowing, accepting, and expressing one's whole self at work. In B. M. Ferdman, \& B. R. Deane (Eds.), Diversity at work: The practice of inclusion: 93-127. San Francisco, CA: Jossey Bass.

Fitzsimmons, S. 2013. Multicultural Employees: A framework for understanding how they contribute to organizations. Academy of Management Review.

Fletcher, J. K. 1999. Disappearing acts: Gender, power, and relational practice at work. Cambridge, MA: MIT Press.

Fletcher, J. K. 2007. Leadership, power, and positive relationships. Exploring positive relationships at work: Building a theoretical and research foundation: 347-371.

Fredrickson, B. L. 2003. Positive emotions and upward spirals in organizations. In K. S. Cameron, J. E. Dutton, \& R. E. Quinn (Eds.), Positive Organizational Scholarship: 163-175. San Francisco: Berrett-Koehler Publishers, Inc.

Gaertner, S., \& Dovidio, J. F. 2000. Reducing intergroup bias: The common ingroup identity model: Psychology Press.

Gallagher, C. A. 2003. Color-blind privilege: The social and political functions of erasing the color line in post race America. Race, Gender, and Class, 10(4): 22-37.

Gerstner, C. R., \& Day, D. V. 1997. Meta-Analytic review of leader-member exchange theory: Correlates and construct issues. Journal of Applied Psychology, 82(6): 827. 
Glynn, M. A. 2000. When Cymbals Become Symbols: Conflict Over Organizational Identity Within a Symphony Orchestra. Organization Science, 11(3): 285-298.

Goodwin, V. L., Bowler, W. M., \& Whittington, J. L. 2009. A social network perspective on LMX relationships: Accounting for the instrumental value of leader and follower networks. Journal of Management, 35(4): 954-980.

Graen, G., \& Schiemann, W. 1978. Leader-member agreement: A vertical dyad linkage approach. Journal of Applied Psychology, 63(2): 206.

Graen, G. B., Liden, R. C., \& Hoel, W. 1982. Role of leadership in the employee withdrawal process. Journal of Applied Psychology, 67(6): 868.

Graen, G. B., \& Scandura, T. A. 1987. Toward a psychology of dyadic organizing. Research in Organizational Behavior.

Graen, G. B., \& Uhl-Bien, M. 1995. Relationship-based approach to leadership: Development of leader-member exchange (LMX) theory of leadership over 25 years: Applying a multi-level multi-domain perspective. The Leadership Quarterly, 6(2): 219-247.

Grumbach, K., Osmond, D., Vranizan, K., Jaffe, D., \& Bindman, A. B. 1998. Primary care physicians' experience of financial incentives in managed-care systems. New England Journal of Medicine, 339(21): 1516-1521.

Harrison, D. A., Price, K. H., \& Bell, M. P. 1998. Beyond relational demography: Time and the effects of surface- and deep-level diversity on work group cohesion. Academy of Management Journal, 41(1): 96-107.

Henderson, D. J., Liden, R. C., Glibkowski, B. C., \& Chaudhry, A. 2009. LMX differentiation: A multilevel review and examination of its antecedents and outcomes. The Leadership Quarterly, 20(4): 517-534. 
Hobfoll, S. E. 1989. Conservation of resources: A new attempt at conceptualizing stress. American Psychologist, 44(3): 513.

Hobfoll, S. E. 2001. The influence of culture, community, and the nested-self in the stress process: advancing conservation of resources theory. Applied Psychology, 50(3): 337421.

Hobfoll, S. E. 2002. Social and psychological resources and adaptation. Review of General Psychology, 6(4): 307.

Hobfoll, S. E. 2011. Conservation of resource caravans and engaged settings. Journal of Occupational and Organizational Psychology, 84(1): 116-122.

Hoff, T. J. 1999. The social organization of physician-managers in a changing HMO. Work and Occupations, 26(3): 324-351.

Jackson, E. M., \& Johnson, R. E. 2012. When opposites do (and do not) attract: Interplay of leader and follower self-identities and its consequences for leader-member exchange. The Leadership Quarterly, 23(3): 488-501.

Jordan, J. V., Kaplan, A. G., Miller, J. B., Stiver, I. P., \& Surrey, J. L. 1991. Women's growth in connection: Writings from the Stone Center. New York: Guilford Press.

Jovanovic, B. 1979. Job matching and the theory of turnover. The Journal of Political Economy: 972-990.

Kahn, W. A. 1990. Psychological Conditions of Personal Engagement and Disengagement at Work. Academy of Management Journal, 33(4): 692-724.

Kahn, W. A. 2007. Meaningful Connections: Positive Relationships and Attachments at Work. In J. E. Dutton, \& B. R. Ragins (Eds.), Exploring Positive Relationships at Work: 189-206. New York: Lawrence Erlbaum Associates. 
Kanter, R. M. 1977. Men and women of the corporation (First ed.). New York: Basic Books.

Kossek, E. E., Pichler, S., Bodner, T., \& Hammer, L. B. 2011. Workplace social support and work-family conflict: A meta-analysis clarifying the influence of general and work-

family-specific supervisor and organizational support. Personnel Psychology, 64(2): 289-313.

Kreiner, G. E., Hollensbe, E. C., \& Sheep, M. L. 2006. Where is the" me" among the" we"? Identity work and the search for optimal balance. Academy of Management Journal, 49(5): 1031-1057.

Ladge, J., Clair, J., \& Greenberg, D. 2012. Cross-domain identity transition during liminal periods: Constructing multiple selves as "professional and mother" during pregnancy Academy of Management Journal, 55(6): 1449-1471.

Leroy, H., Anseel, F., Gardner, W. L., \& Sels, L. 2012. Authentic leadership, authentic followership, basic need satisfaction, and work role performance: A cross-level study. Journal of Management: 0149206312457822.

Liden, R. C., \& Graen, G. 1980. Generalizability of the vertical dyad linkage model of leadership. Academy of Management Journal, 23(3): 451-465.

Liden, R. C., Sparrowe, R. T., \& Wayne, S. J. 1997. Leader-member exchange theory: The past and potential for the future. In G. R. Ferris (Ed.), Research in personnel and human resources management, Vol. 15: 47-119. Oxford, UK: Elsevier Science/JAI Press. 
Liden, R. C., Wayne, S. J., \& Stilwell, D. 1993. A longitudinal study on the early development of leader-member exchanges. Journal of Applied Psychology, 78(4): 662.

Lin, N. 2002. Social capital: A theory of social structure and action. New York Cambridge University Press.

Linville, P. W. 1987. Self-complexity as a cognitive buffer against stress-related illness and depression. Journal of Personality and Social Psychology, 52(4): 663.

Lord, R. G., \& Brown, D. J. 2004. Leadership processes and follower self-identity. Mahwah, NJ: Lawrence Erlbaum Associates, Inc.

Mahler, M. S. 1972. On the first three subphases of the separation-individuation process. The International Journal of Psychoanalysis, 53(3): 333-338.

Maitlis, S. 2009. Who am I now? Sensemaking and identity in posttraumatic growth. In L. M. Roberts, \& J. Dutton (Eds.), Exploring positive identities and organizations: 47-76. New York: Routledge Taylor and Francis Group.

March, J. G. 1991. Exploration and exploitation in organizational learning. Organization Science, 2(1): 71-87.

Miller, J. B. 1976. Toward a new psychology of women. Boston: Beacon Press.

Miller, J. B. 1986. Toward a new psychology of women (Second Edition ed.). Boston: Beacon.

Miller, J. B., \& Stiver, I. P. 1997. The healing connection. Boston, MA: Beacon Press. Miller, R. A. 1984. Job matching and occupational choice. The Journal of Political Economy: 1086-1120.

Mohr, L. B. 1982. Explaining Organizational Behavior. San Francisco: Jossey-Bass 
Nembhard, I., \& Edmondson, A. 2011. Psychological safety: A foundation for speaking up, collaboration and experimentation. In K. Cameron, \& G. Spreitzer (Eds.), The Oxford handbook of positive organizational scholarship. New York: Oxford University Press.

Nembhard, I. M., \& Edmondson, A. C. 2006. Making it safe: The effects of leader inclusiveness and professional status on psychological safety and improvement efforts in health care teams. Journal of Organizational Behavior, 27(7): 941-966.

Ng, T. W., \& Feldman, D. C. 2012. Employee voice behavior: A meta-analytic test of the conservation of resources framework. Journal of Organizational Behavior, 33(2): 216-234.

Oakes, P. J. 1987. The salience of social categories. In J. Turner, M. Hogg, P. Oakes, S. Reicher, \& M. Wetherell (Eds.), Rediscovering the social group: A selfcategorization theory: 117-141. Oxford: Blackwell.

Paglis, L. L., \& Green, S. G. 2002. Both sides now: Supervisor and subordinate perspectives on relationship quality. Journal of Applied Social Psychology, 32(2): 250-276.

Perlow, L. A. 1995. Putting the work back into work/family. Group \& Organization Management, 20(2): 227-239.

Phillips, A. S., \& Bedeian, A. G. 1994. Leader-follower exchange quality: The role of personal and interpersonal attributes. Academy of Management Journal, 37(4): 9901001.

Polzer, J. T., Milton, L. P., \& Swann, W. B. 2002. Capitalizing on diversity: Interpersonal congruence in small work-groups. Administrative Science Quarterly: 296-324. 
Prasad, P., Pringle, J. K., \& Konrad, A. M. 2006. Examining the contours of workplace diversity: Concepts, contexts and challenges. In A. M. Konrad, P. Prasad, \& J. K. Pringle (Eds.), Handbook of workplace diversity. Thousand Oaks: Sage Publications.

Pratt, M. G. 2000. The good, the bad, and the ambivalent: Managing identification among Amway distributors. Administrative Science Quarterly, 45(3): 456-493.

Pratt, M. G., Fiol, C. M., O'Connor, E. J., \& Panico, P. 2012. Promoting positive change in physician-administrator relationships: The importance of identity security in managing intractable identity conflicts. In K. Golden-Biddle, \& J. E. Dutton (Eds.), Using a positive lens to explore social change and organizations: Building a theoretical and research foundation: 267-288. New York: Routledge.

Pratt, M. G., \& Rafaeli, A. 1997. Organizational Dress as a Symbol of Multilayered Social Indentities. Academy of Management Journal, 40(4): 862-898.

Ragins, B. R., \& Dutton, J. E. 2007. Positive relationships at work: An introduction and invitation, Exploring positive relationships at work: Building a theoretical and research foundation: 3-25. New York: Lawrence Erlbaum Associates, Inc.

Ragins, B. R., Singh, R., \& Cornwell, J. M. 2007. Making the invisible visible: fear and disclosure of sexual orientation at work. Journal of Applied Psychology, 92(4): 1103.

Ramarajan, L. 2014. Past, present and future research on multiple identities: Toward an intrapersonal network approach. The Academy of Management Annals, 8(1): 589659.

Ramarajan, L., \& Reid, E. 2013. Shattering the myth of separate worlds: Negotiating nonwork identities at work. Academy of Management Review, 38(4): 621-644. 
Reybold, L. E., \& Alamia, J. J. 2008. Academic transitions in education: A developmental perspective of women faculty experiences. Journal of Career Development, 35(2): $107-128$.

Roberts, L. 2013. Reflected best self engagement at work: Positive identity, alignment, and the pursuit of vitality and value creation. In I. Boniwell, \& S. David (Eds.), The Oxford Handbook of Happiness: 767-782. New York: Oxford University Press.

Roberts, L. M., Cha, S. E., Hewlin, P. F., \& Settles, I. H. 2009. Bringing the inside out: Enhancing authenticity and positive identity in organizations, Exploring positive identities and organizations: Building a theoretical and research foundation: 149170. NY: Routledge.

Roberts, L. M., \& Creary, S. J. 2011. Positive identity construction: Insights from classical and contemporary theoretical perspectives. In K. S. Cameron, \& G. Spreitzer (Eds.), The Oxford handbook of positive organizational scholarship: 70-83. New York: Oxford University Press.

Roberts, L. M., \& Roberts, D. D. 2007. Testing the limits of antidiscrimination law: The business, legal, and ethical ramifications of cultural profiling at work. Duke Journal of Gender Law \& Policy, 14: 369-405.

Roberts, L. M., Wooten, L., \& Davidson, M. forthcoming. Positive organizing in a global society: Understanding and engaging differences for capacity-building and inclusion. New York: Routledge Taylor \& Francis Group.

Rosenthal, P. 1995. Gender differences in managers' attributions for successful work performance. Women in Management Review, 10(6): 26-31. 
Rosenthal, P. 1996. Gender and managers' causal attributions for subordinate performance: A field story. Sex Roles, 34(1): 1-15.

Rousseau, D., \& Ling, K. 2007. Commentary: Following the resources in positive organizational relationships. In J. Dutton, \& B. Ragins (Eds.), Exploring positive relationships at work: Building a theoretical and research foundation: 373-384. NY: Lawrence Erlbaum Associates.

Rudman, L. A. 1998. Self-promotion as a risk factor for women: the costs and benefits of counterstereotypical impression management. Journal of Personality and Social Psychology, 74(3): 629.

Sanchez-Burks, J. 2002. Protestant relational ideology and (in) attention to relational cues in work settings. Journal of Personality and Social Psychology, 83(4): 919.

Sanchez-Burks, J. 2004. Protestant relational ideology: The cognitive underpinnings and organizational implications of an American anomaly. Research in Organizational Behavior, 26: 265-305.

Scandura, T. A., \& Pellegrini, E. K. 2008. Trust and leader-member exchange: A closer look at relational vulnerability. Journal of Leadership \& Organizational Studies, 15(2): 101-110.

Shamir, B., House, R. J., \& Arthur, M. B. 1993. The motivational effects of charismatic leadership: A self-concept based theory. Organization Science, 4(4): 577-594.

Sluss, D. M., \& Ashforth, B. E. 2007. Relational identity and identification: Defining ourselves through work relationships. Academy of Management Review, 32(1): 9-32.

Sonenshein, S. 2014. How Organizations Foster the Creative Use of Resources. Academy of Management Journal, 57(3): 814-848. 
Sparrowe, R. T., \& Liden, R. C. 1997. Process and structure in leader-member exchange. Academy of Management Review, 22(2): 522-552.

Sparrowe, R. T., \& Liden, R. C. 2005. Two Routes to Influence: Integrating Leader-Member Exchange and Social Network Perspectives. Administrative Science Quarterly, 50(4): 505-535.

Starrels, M. E. 1992. The evolution of workplace family policy research. Journal of Family Issues, 13(3): 259-278.

Stets, J. E., \& Burke, P. J. 2000. Identity theory and social identity theory. Social Psychology Quarterly: 224-237.

Stryker, S. 1980. Symbolic interactionism: A social structural version. Menlo Park, CA: Benjamin Cummings.

Stryker, S., \& Burke, P. J. 2000. The past, present, and future of an identity theory. Social Psychology Quarterly, 63(4): 284-297.

Swann, W. B., \& Bosson, J. K. 2008. Identity negotiation: A theory of self and social interaction. In O. John, R. Robins, \& L. Pervin (Eds.), Handbook of personality: Theory and research: 448-471. New York: Guilford Press.

Swann, W. B., Johnson, R. E., \& Bosson, J. K. 2009. Identity negotiation at work. Research in Organizational Behavior, 29(81): 109.

Tajfel, H., \& Turner, J. C. 1979. An integrative theory of intergroup conflict. In W. G. Austin, \& S. Worchel (Eds.), The social psychology of group relations: 33-47. Monterey, CA: Brooks-Cole.

Thoits, P. A. 1983. Multiple identities and psychological well-being: A reformulation and test of the social isolation hypothesis. American Sociological Review, 48(2): 174-187. 
Thomas, D. 1993. The dynamics of managing racial diversity in developmental relationships. Administrative Science Quarterly, 38: 169-194.

Thomas, D. A., \& Ely, R. J. 1996. Making differences matter. Harvard Business Review, 74(5): 79-90.

Thomas, L. T., \& Ganster, D. C. 1995. Impact of family-supportive work variables on workfamily conflict and strain: A control perspective. Journal of Applied Psychology, 80(1): 6 .

Tsui, A. S., Pearce, J. L., Porter, L. W., \& Tripoli, A. M. 1997. Alternative approaches to the employee-organization relationship: does investment in employees pay off? Academy of Management Journal, 40(5): 1089-1121.

Turner, J. C. 1982. Towards a cognitive redefinition of the social group. Social identity and intergroup relations: $15-40$.

Vandenberg, R. J., \& Scarpello, V. 1990. The matching model: An examination of the processes underlying realistic job previews. Journal of Applied Psychology, 75(1): 60.

Vermeulen, F., \& Barkema, H. 2001. Learning through acquisitions. Academy of Management Journal, 44(3): 457-476.

Vondey, M. 2008. Follower-focused leadership: Effect of follower self-concepts and selfdetermination on organizational citizenship behavior. Emerging Leadership Journeys, 1(1): 52-61.

Vroom, V. H. 2007. On the synergy between research and teaching. Journal of Management Education, 31(3): 365-375. 
Weick, K. E., \& Roberts, K. H. 1993. Collective mind in organizations: Heedful interrelating on flight decks. Administrative Science Quarterly: 357-381.

West, M. A., \& Farr, J. L. 1989. Innovation at work: Psychological perspectives. Social Behaviour, 4(1): 15-30.

Wilk, S. L., \& Moynihan, L. M. 2005. Display rule" regulators": the relationship between supervisors and worker emotional exhaustion. Journal of Applied Psychology, 90(5): 917.

Wilson, K. S., Sin, H.-P., \& Conlon, D. E. 2010. What about the leader in leader-member exchange? The impact of resource exchanges and substitutability on the leader. Academy of Management Review, 35(3): 358-372.

Yoshino, K. 2002. Covering. The Yale Law Journal, 111(4): 769-939. 


\section{FIGURE 1}

A Typology of Resource Utilization as Predicted by Manager and Subordinate Strategies for

Managing a Subordinate's Multiple Identities

Manager's Strategy

Exclusionary Inclusionary

Subordinate's Strategy

\begin{tabular}{|l|l|}
\hline Resource Exchange & Resource Exploitation \\
\hline Resource Suppression & \\
& \\
& \\
\hline
\end{tabular}




\section{FIGURE 2}

A Model of the Effect of Managing a Subordinate's Multiple Identities on Resource Utilization and the

\section{Quality of a Manager-Subordinate Relationship}

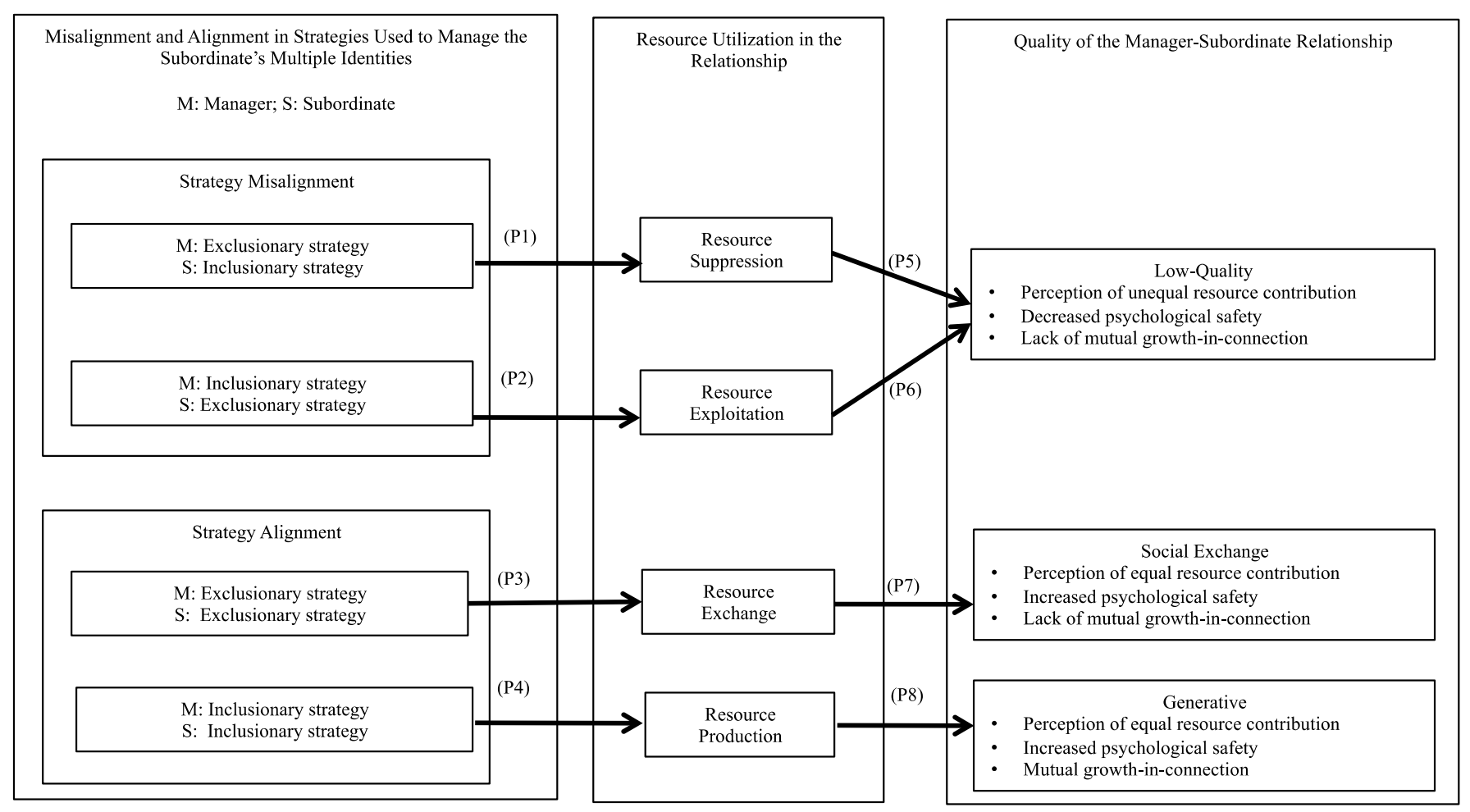


Stephanie J. Creary (sjcreary@gmail.com) is a Ph.D. candidate in the Management and Organization Department at the Boston College Carroll School of Management. Her research examines questions related to identities and resources including how they emerge and affect workplace relationships, generativity, and the broader organizational environment.

Brianna Barker Caza (brianna.caza@ umanitoba.ca) is an associate professor in the Asper School of Business at the University of Manitoba. She received her Ph.D. in Organizational Psychology from the University of Michigan. The overall aim of her research program is to understand the resources and processes that produce resilience at work.

Laura Morgan Roberts (lroberts3@ antioch.edu) is a professor in Antioch University’s Ph.D. Program in Leadership and Change. She is also a core faculty affiliate of the Center for Positive Organizations. Her research examines questions related to authenticity, identities, diversity, and best self engagement. She earned her MA and Ph.D. (Organizational Psychology) from the University of Michigan. 